Article

\title{
Urban Heritage Conservation of China's Historic Water Towns and the Role of Professor Ruan Yisan: Nanxun, Tongli, and Wuzhen
}

\author{
Heleni Porfyriou \\ Department of Social Sciences and Humanities, Cultural Heritage, CNR - National Research Council of Italy, \\ 00186 Rome, Italy; heleni.porfyriou@cnr.it
}

Received: 23 June 2019; Accepted: 10 August 2019; Published: 13 August 2019

\begin{abstract}
Between the 13th and the 19th century, hundreds of water towns flourished in China along the Grand Canal and to the south of the Yangtze river, the latter being the focus of this paper. Despite their long history, water towns still lack a comprehensive account of their urban history and development, yet they have become world famous as tourist destinations. Initially branded under titles such as the "Venice of the East" or the "Venice of China", they are visited nowadays, for their own sake and not as surrogates of Venice, by millions of Chinese tourists. Focusing on the urban form and heritage of the three historic water towns of Nanxun, Tongli and Wuzhen, and on their conservation planning as promoted by Professor Ruan Yisan since the mid-1980s, the aim of this paper is twofold. On one hand, the aim is to identify and examine, through personal observation and secondary sources, the urban patterns and morphology of these places; on the other hand, to explore through his publications the impact of Professor Ruan Yisan-a (if not the) key figure-in their conservation and tourist development. The paper's broader aim is to contribute to a more systematic analytical approach towards the urban form of Chinese historic water towns as a basis for further research and heritage conservation planning.
\end{abstract}

Keywords: Chinese historic water towns; urban form and conservation; heritage tourism; Ruan Yisan; Nanxun; Tongli; Wuzhen

\section{Introduction: Water Towns-A Story Still to be Written}

Water towns have a long history that is closely linked to the natural configuration of the land, particularly in East China, which "is so dense with waterways and small lakes that the map looks more like a cross-section through a sponge" (Figure 1), as Philip Ball put it in his fascinating book The Water Kingdom. A Secret History of China [1] (p. 127). Their development was strongly dependent on the - until recently - predominantly agricultural economy of China (Figure 2), while their history is closely related to the big commercial route of the Grand Canal and its ingenious hydraulic works, dating back to the Sui (581-618 C.E.) and Tang (618-907 C.E.) dynasties (Figure 3).

"On a good day a riverboat could hope to cover fifteen to twenty-five kilometres. The imperial grain vessels seldom kept the same crew from start to end of a journey — there would be changes along the way [Grand Canal], and sometimes the grain might be stored in granaries en route if repairs or bad weather impeded progress. The lives of the river merchants and their captains were a constant procession of misty peaks and water towns, as elegantly conveyed by the Song painter Zhang Zeduan [2] in his famous scroll painting Along the River During the Qingming Festival". [1] (p. 121) (Figure 4)

Hundreds of water towns were built along watercourses. A significant number of them, located both south of the Yangtze river and along the Grand Canal, have been greatly influenced and developed 
in relation to the impact of this imposing communication and commercial route (measuring around $1800 \mathrm{~km}$ in the 13th century), which connected Hangzhou, in the southern part of the empire, to Beijing, in northern China (Figure 3). "Constructed in sections from the 5th century BC onwards, it was conceived as a unified means of communication for the Empire for the first time in the 7th century AD (Sui dynasty)" [3]. Around the 12th century, the Grand Canal became the most important north to south communication artery of China, and when, during the Song Dynasty (in 1127), the capital was moved to Hangzhou on the Canal, south China became the center of the whole country and the water towns of the Yangtze delta were boosted in both economic and cultural terms. ${ }^{1}$ As a Chinese proverb says "the harvest of Suzhou and Huzhou feeds the whole world" [4] (p. 21).

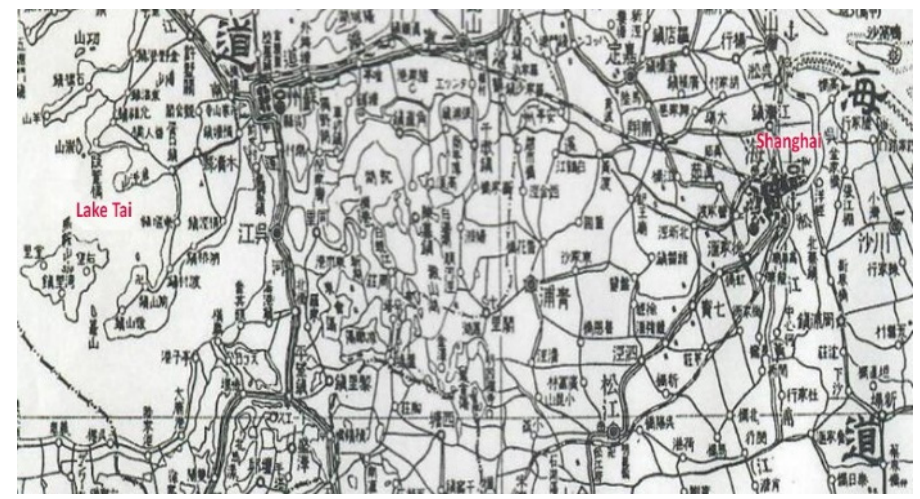

Figure 1. Hydrographic basin of Shanghai Region, 1930 (re-elaborated by the author).

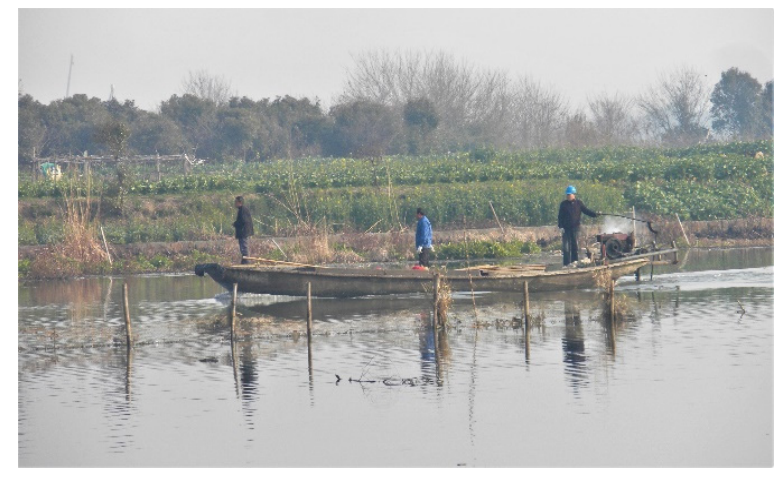

Figure 2. Rural landscape near Tongli, 2015 (photo by the author).

The Grand Canal was added to the list of UNESCO World Heritage Sites in 2014, and this gave a new impetus to the opening and promotion of at least 40 new heritage sites along its course [5]. However, despite this long and rich history, water towns still lack a comprehensive account of their urban history, ${ }^{2}$ or at least a history of the urban morphology and evolution of the more homogeneous

1 The Yangtze region was always of great economic importance to successive dynasties for its agricultural potential. The areas around the cities of Huzhou and Suzhou (situated respectively in the south and north east of Tai lake) and south of the Yangtze river, in Zhejiang province, due to their abundant watercourses, were the grain baskets of China. The Grand Canal was built, in fact, in order to transport grain from the Yangtze basin to the great northern capital cities. "The management of the Grand Canal was made possible over a long period by means of the Caoyun system, the imperial monopoly for the transport of grain and strategic raw materials, and for the taxation and control of traffic. The system enabled the supply of rice to feed the population, the unified administration of the territory, and the transport of troops." [3].

2 The reason why the recent inscription of the Grand Canal in the UNESCO WHS didn't manage to promote a more in-depth historical analysis of the water towns and of their development is due, in our view, to the fact that the inscription was focused on the hydraulic importance of the Grand Canal works and of the archaeological excavations related to them, and not on the historical development of the sites and water towns developed along it [5]. 
clusters, such as the one we will focus on in this paper, ${ }^{3}$ located to the south of the Yangtze river in the Jiangsu-Zhejiang provinces [6-8].

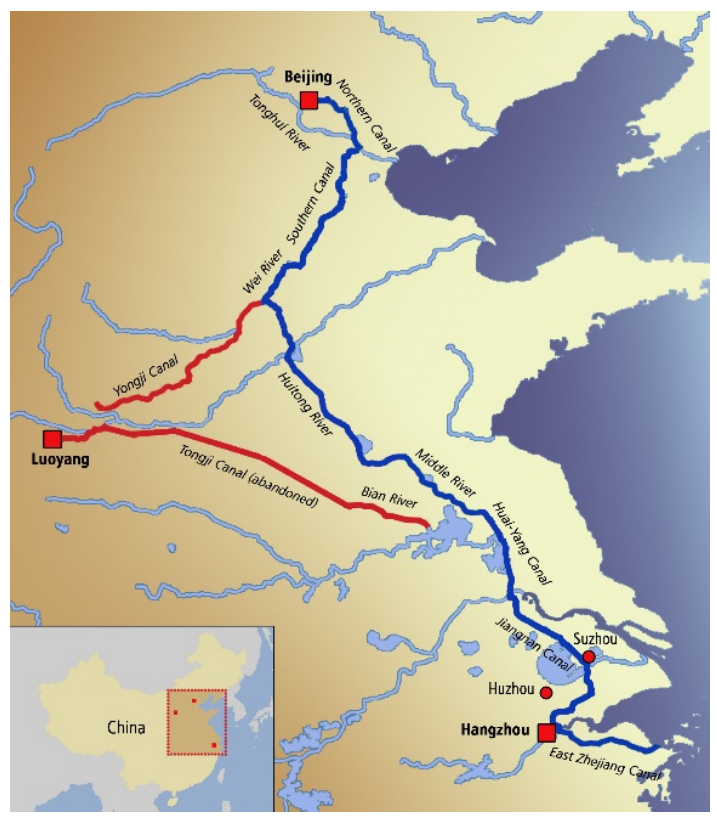

Figure 3. Map of the Grand Canal. The Sui Dynasty Canal is shown in red (elaborated by Paola Brunori).

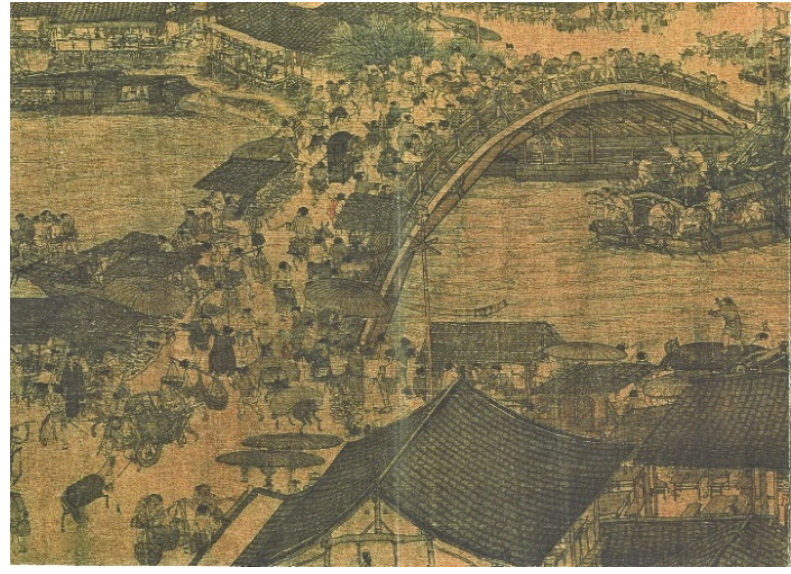

Figure 4. Zhang Zeduan, famous scroll painting Along the River During the Qingming Festival. Detail of "rainbow bridge" spanning the Bianhe river, 18th century edition of the 12th century scroll.

Although they lack a dedicated history or a place in urban history books ${ }^{4}$ [9], water towns have nevertheless become world famous as tourist destinations. Branded as the "Venice of the East" or the "Venice of China" [10], they are nowadays visited for their own sake, and not as surrogates of Venice, by millions of Chinese tourists (Tongli has received more than 2 million visitors yearly since 2008 [11]

3 Fei Xiaotong [6] by conducting a series of surveys was the first to bring the attention back to these small urban centres. Ruan Yisan, instead, since 1986 was the first to focus on these towns' historic urban heritage, promoting an alternative way to their development [7]. Within the Jiangnan region (literally meaning south of the river) may be identified more than one clusters of water towns, such as for example the one discussed in this article, or the one forming the Shaoxing Prefecture city (with a population of approximately 5 million in 2010) [8].

4 Research on urban history, in general, is still lagging behind in China and in particular studies regarding urban physical form and morphology are as yet not well established [. One of the few well done works on the subject and relative to the city of Suzhou is [9]. 
(p. 8); Wuzhen received almost 7 million in 2014, with an increase of $21.67 \%$ compared to the previous year [12]).

Considered the best exemplars of the peaceful and traditional slow-living style that has only recently faded from existence, they represent the myth of the small town, close to the countryside, but easily accessible from big metropolitan agglomerations such as Shanghai. Today, these water cities are no longer "small towns", nor "closely related to the countryside", yet the myth still persists. Large cities have grown around their ancient historic centers, often with important industrial districts that reduce the importance of any productive relationship to the countryside. The numbers speak for themselves: in 2015, the population of the historic water town of Tongli was approximately 11,000, while that of Tongli city was approximately 60,000 and the Wujiang District population reached 1,300,000 inhabitants [13]. Nevertheless, the description of Tongli on the Suzhou provincial government tourist website stresses the city's ancient relationship to the countryside without making any reference to today's city extension and population, as the following quotation illustrates:

"Being an ancient township, Tong Li borders on Tongli Lake on the east, Nanxin Lake on the south, adjoins Pangshan Lake on the west, Jiuli Lake on the north and Wusong Jiang River on the northwest. The town proper is divided by the streams into seven islets interlaced with the surrounding water area, forming typical water county of the south". [14]

The overview that follows of the historic water towns to the south of the Yangtze river, based on secondary sources and on first-hand observation, aims to identify some threads of urban history and major urban patterns on which to build future research on historic water town conservation. In parallel, the paper focuses on the impact Professor Ruan Yisan's conservation planning has had since 1985 on the tourist development of three representative cases: Nanxun, Tongli and Wuzhen, thus highlighting through a critical presentation and assessment limits and potentialities.

\section{Historic Water Towns to the South of the Yangtze River: Urban Form and Heritage}

Between the 13th and 19th centuries, hundreds of water towns flourished to the south of the Yangtze river (that is, in the south of Jiangsu Province and north of Zhejiang Province), as evidenced in the built heritage from the Ming and Qing Dynasties (1368-1911 C.E.) that is still standing in these towns.

The "bridge-water-house" trinity (Figure 5) represents a typical feature of these water towns. Ruan Yisan-who was the first to study water towns and propose plans for their conservation [7], from the mid-1980s onwards—summarised their development patterns as follows:

"Where there is only one river across the town, a belt-shaped town is formed. Where there are two or more rivers, a cross-shaped or tree-crotch-shaped town is formed (such as Wuzhen or Zhouzhuang, Figure in Section 5). Where there are four or even more rivers running through the town, grid-shaped towns are formed (such as Tongli, Figure 6).". [4] (p. 25)

Water is, therefore, the driving force in the urban development and the street network of water towns. Traditionally, waterways had a more important role than streets, as goods were shipped into the towns from the countryside and all commercial activities took place on the wharfs, where marketplaces naturally formed. 


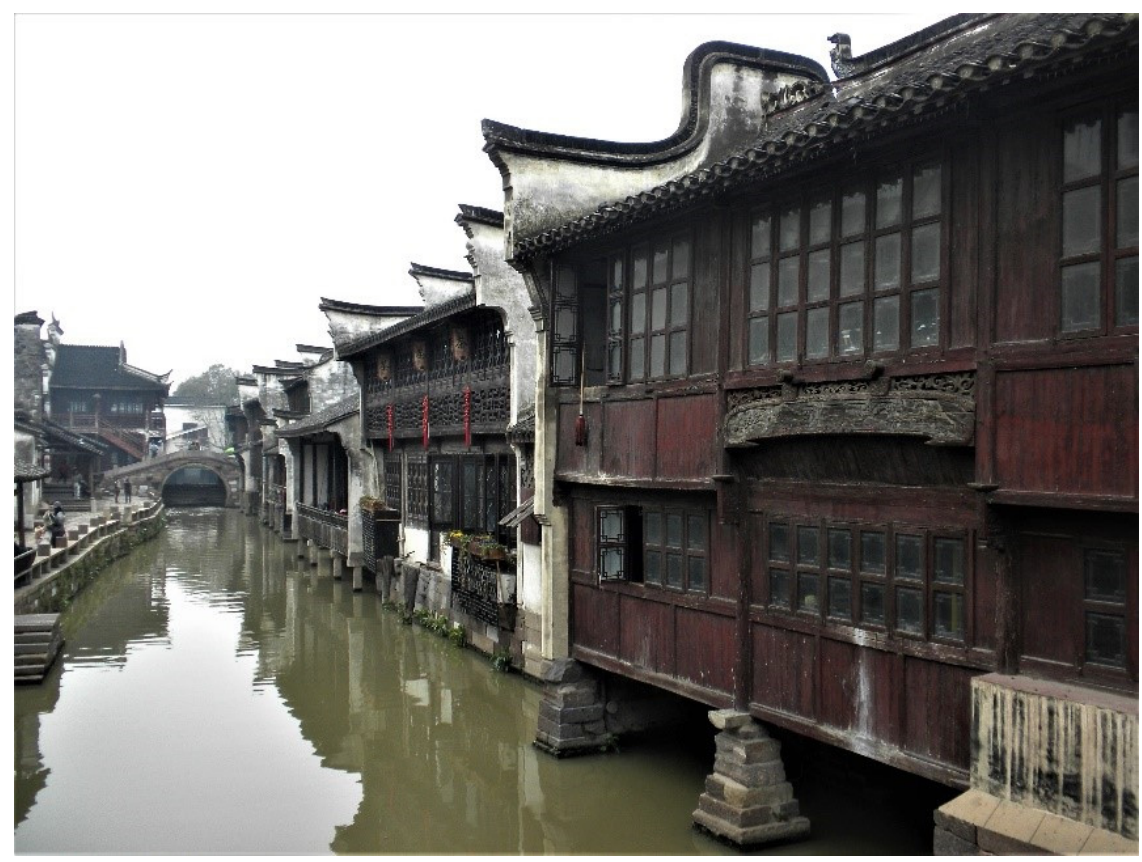

Figure 5. The "bridge-water-house" trinity, Wuzhen, 2015 (photo by the author).

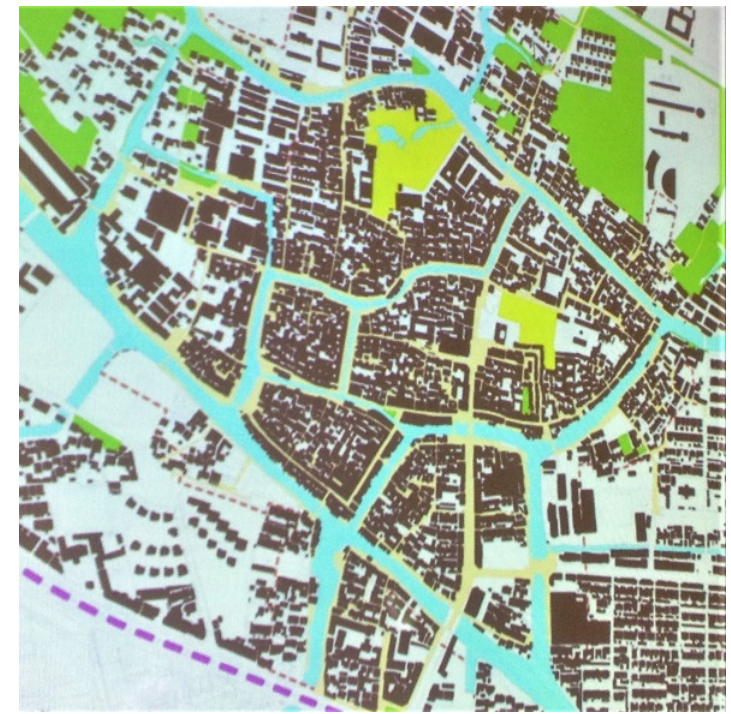

Figure 6. A grid-shaped water town, Tongli (re-elaborated by the author).

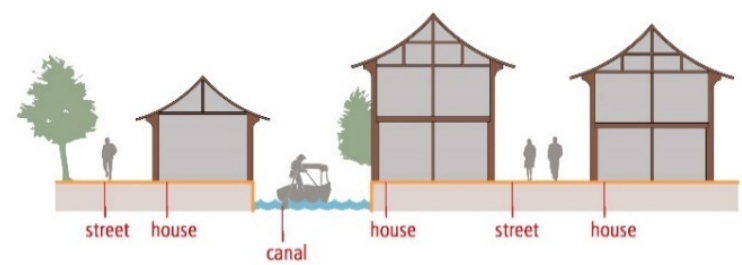

Figure 7. Diagram of the "one street one river" urban pattern prevailing in water towns south of the Yangtze (elaborated by Paola Brunori).

On a neighbourhood level, streets tend to develop in parallel to the rivers, due to the convenience afforded by access to both water and land. Houses are intentionally built next to the water, with the street in front and the river at the back. The pattern of one street, one river (Figure 7), or one river two streets, are the prevailing patterns in water towns south of the Yangtze [15]. Streets are aligned 
with one- to two-storey, dark tile-roofed buildings with uninterrupted, wooden facades (Figure 8). The ground floor is often given over to workshops, stores or shops, with houses on the shallower second floor. These usually wooden-structured traditional buildings often have whitewashed brick facades, ornamented at times with wooden carvings, and are separated by intermittent brick-stepped, gabled firewalls (Figures 5 and 9).

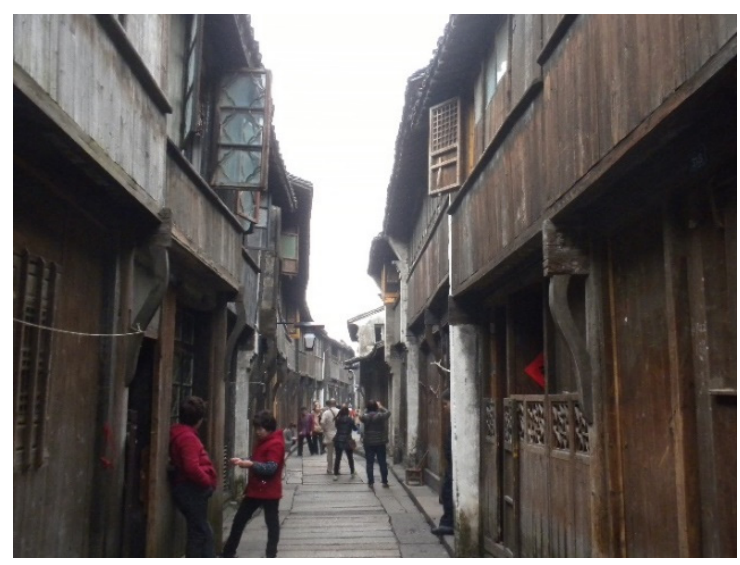

Figure 8. Street view, Wuzhen, 2015 (photo by the author).

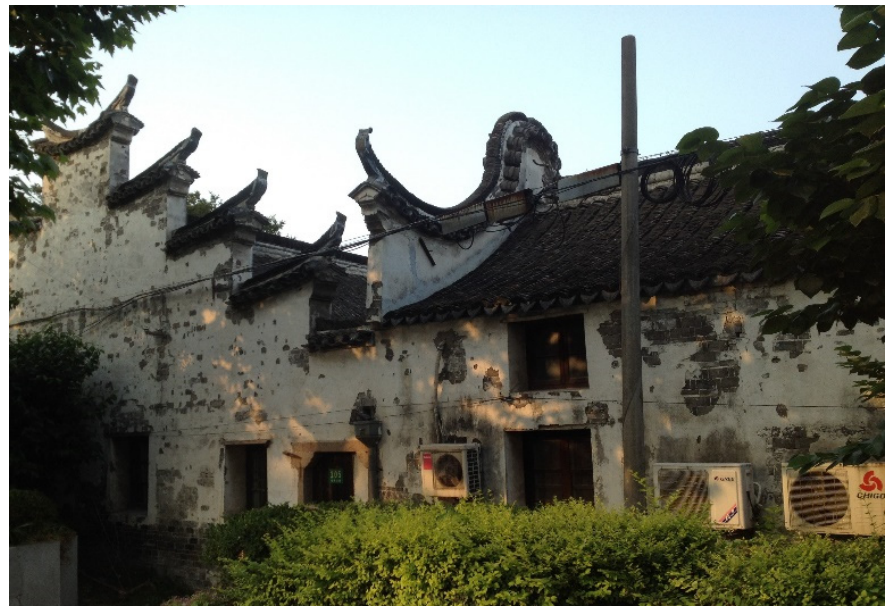

Figure 9. Residential area, Xinchang, 2014 (photo by the author).

Wealthy families often occupy both sides of a street, locating the warehouses of their commercial activities next to the river-thus having private docks and direct access to water transportation; and keeping shop premises across the street, with residential rooms situated behind the shops (as the Zhenze city model shows, see Figure 10). Houses are often arranged in the traditional style of siheyuan - that is, around courtyards (Figure 11). The richer the family, the more complex the combination of courtyards and of private gardens [16], with pavilions (Figure 12) that follow the model of the famous classic garden mansions of the cities of Suzhou and Hangzhou. The wealthier the family, the more suites of rooms were added. ${ }^{5}$ Family wealth and power was expressed not only in building imposing mansions, but also in erecting "spirit or screen walls" [17] in front of the houses (Figure 13), or in toponymy and street names, as the surviving stone panels give evidence. Some of the waterfront houses, typical of Wuzhen, (Figure 5) were built on wooden stakes or stone pillars, overhanging the river and therefore extending their private space above it.

5 "Wealthy businessman or important government officials had big houses lying lengthways in 'jin' or transversely in 'luo'" [4] (p. 111) 


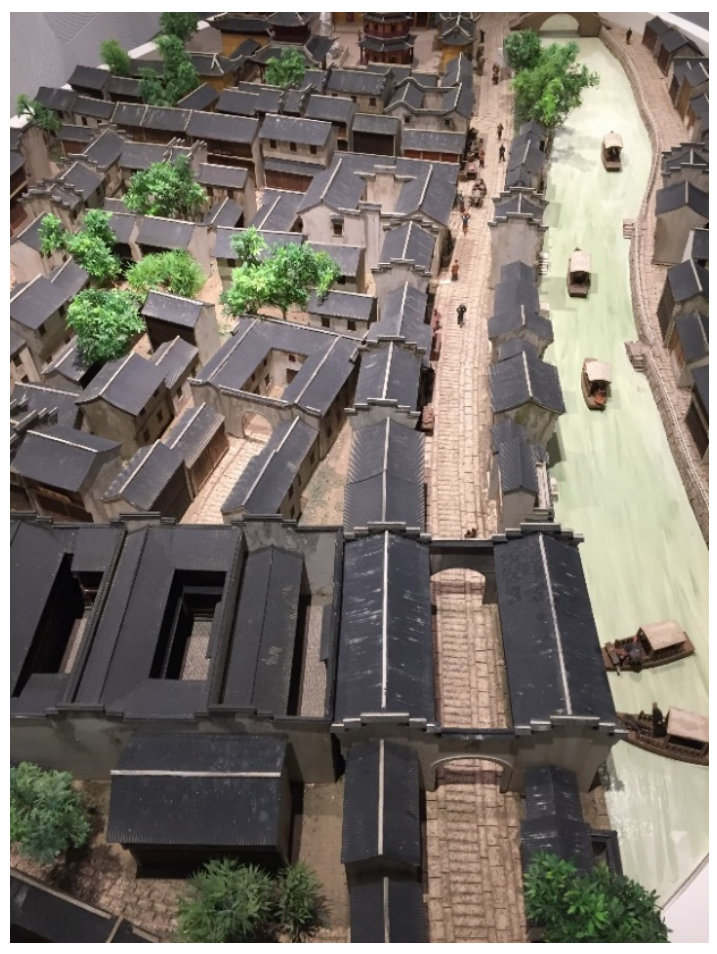

Figure 10. A wealthy family disposition of space, with warehouses next to the river and shop premises across the street. Zhenze city model, 2017 (photo by the author).

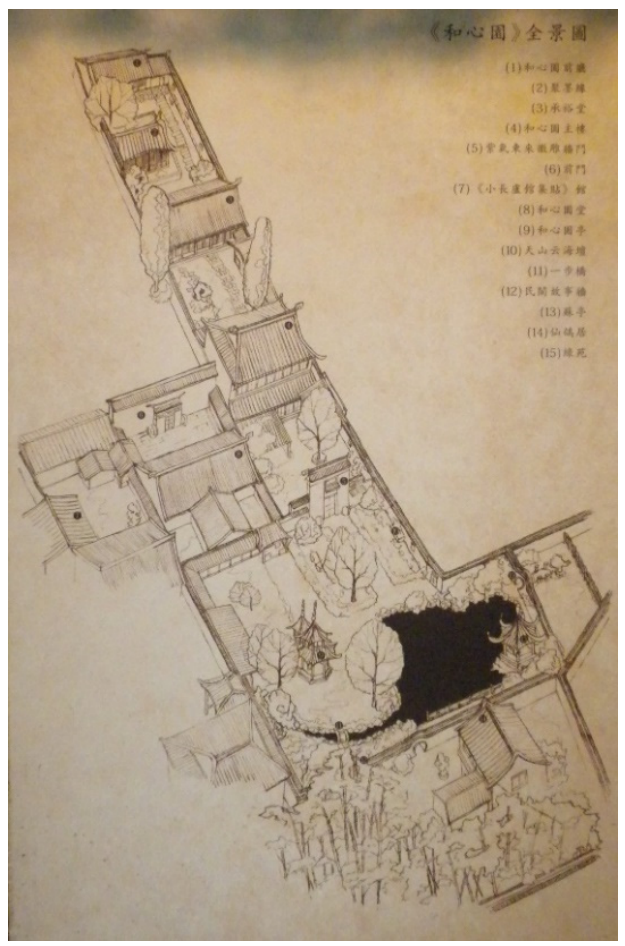

Figure 11. A wealthy house arranged in the traditional style of siheyuan, Kezhi garden mansion, Zhoujiajiao, 2018 (photo by the author). 


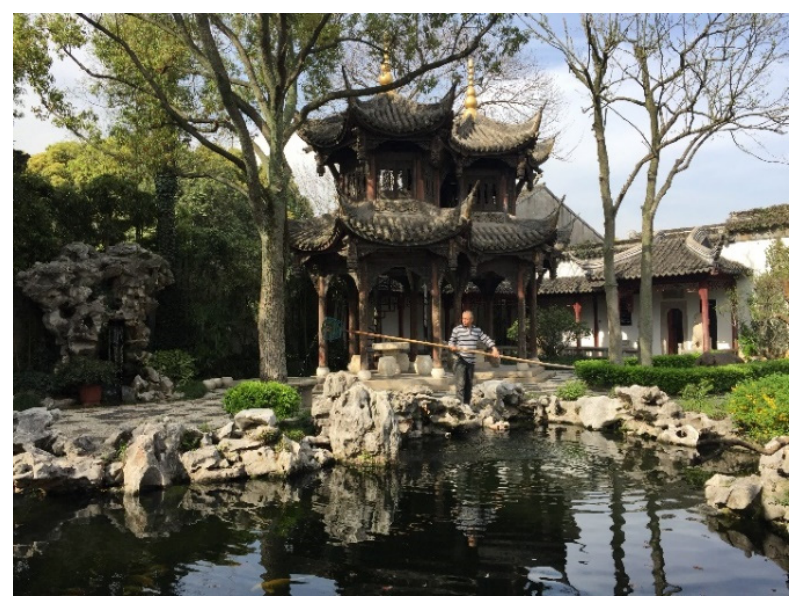

Figure 12. Pavillion in Kezhi gardens, Zhoujiajiao, 2018 (photo by the author).

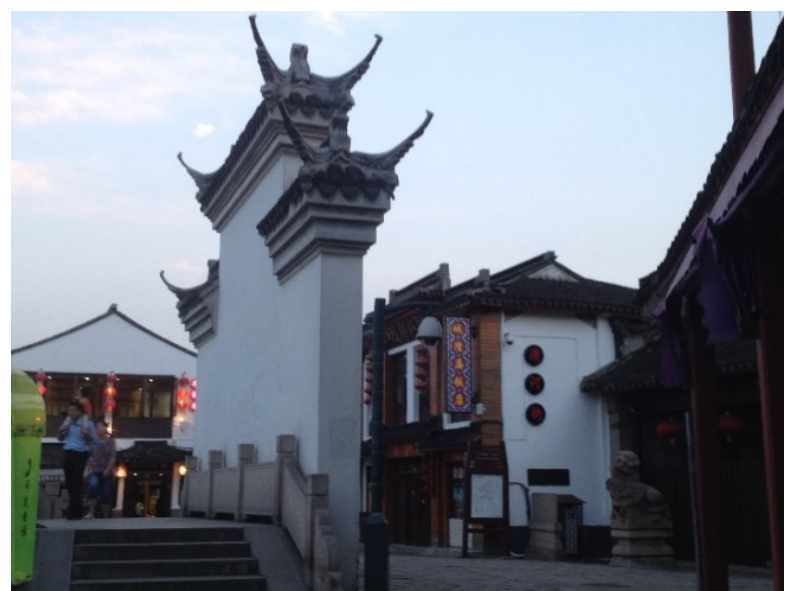

Figure 13. Spirit wall in front of wealthy mansion, Zhoujiajiao, 2015 (photo by the author).

Traditional commercial streets with their wooden, double-storey buildings, often running in parallel to the river, were the core of city life. Beidajie, one of the oldest paved streets of Zhujiajiao that still maintains a significant number of old stores, is quite representative: with a width of 2-4 meters, it has shops on both sides at ground level, and residential facilities on the upper floor or at the rear of the business premises. Some shops occupy a space of only one room, while other store fronts bring together up to 3-4 rooms (Figure 14a,b). The sliding, removable wooden planks, which open the entire façade of the shop to the street, give a colourful view of these crowded commercial places during working hours, while at closing time, the repositioning of the wooden planks recreates the street's compact traditional outline. Major streets are intersected by a number of narrow residential lanes, often wide enough only for a single pedestrian. Big stone slabs pave these lanes and whitewashed high brick walls enclose them on both sides, with almost no window openings (Figure 15a,b). Only narrow gates interrupt the spatial continuity of these narrow residential lanes. 


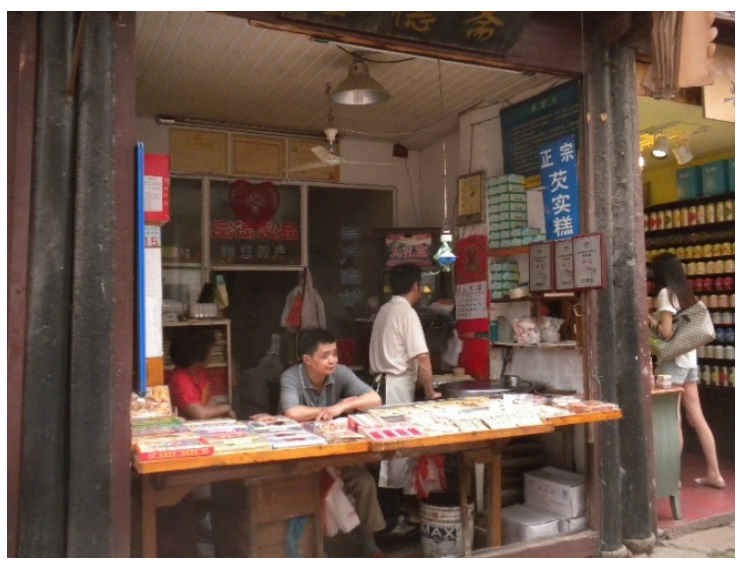

(a)

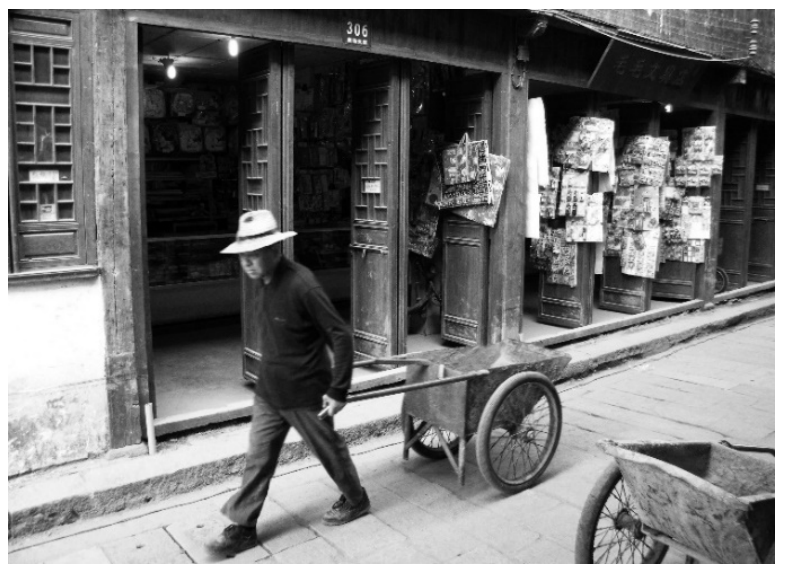

(b)

Figure 14. (a) One-room shop (photo by the author). (b) Shop premises, with sliding removable wooden planks, occupying three rooms (photo by the author).

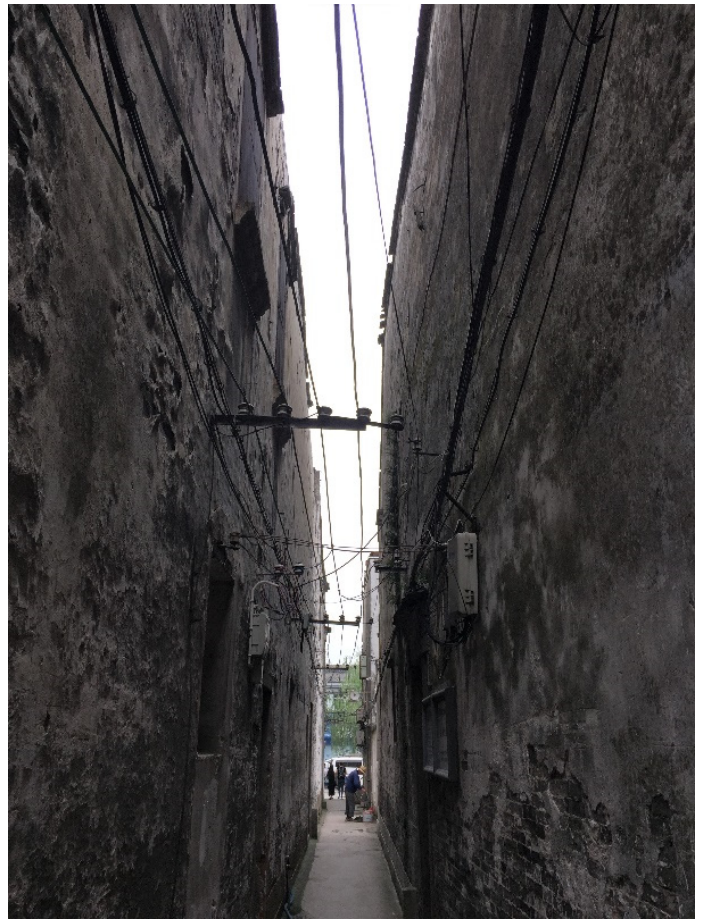

(a)

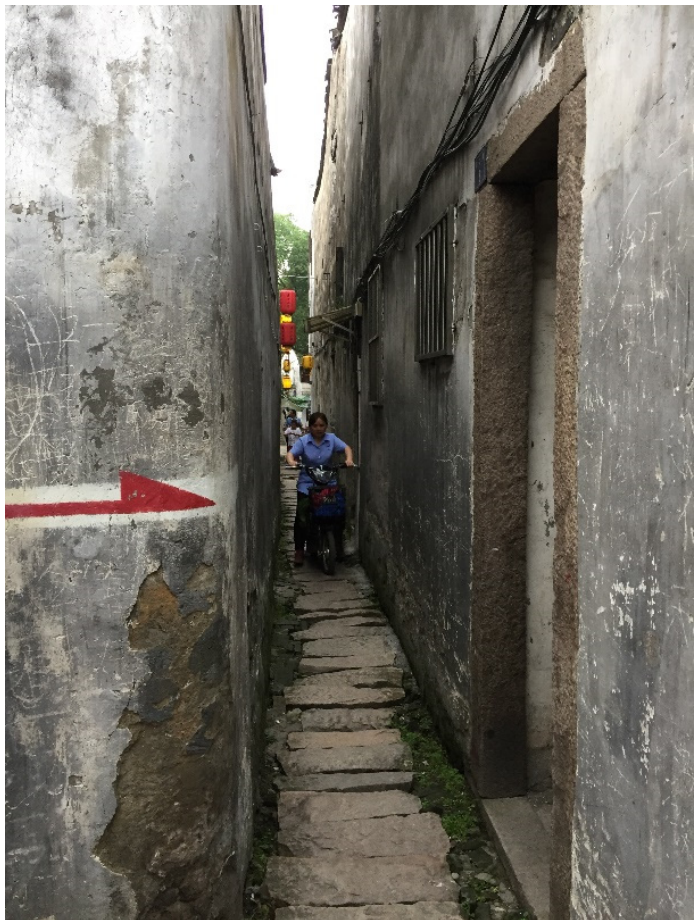

(b)

Figure 15. (a) Narrow residential lane, Zhenze, 2017 (photo by the author). (b) Narrow residential lane, Tongli, 2015 (photo by the author).

All the river and canal fronts that cross the water towns have stone revetments, thus protecting the river bank from collapsing. Along them there are private piers (directly serving houses or shops), while boats can dock alongside the streets and residents may descend to the water level to do their washing on regularly-placed flights of stone stairs (Figure 16a,b). Traditionally, boats were moored along the banks on purpose-sculpted stones of different forms (representing, for example, an ox nose, twin coins, palm leaves, or an s-shaped ornament), and many still survive, serving the same purpose. 


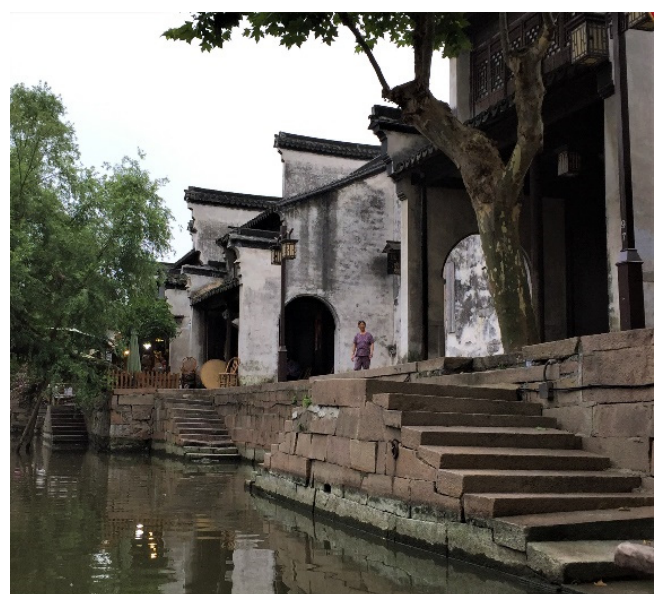

(a)

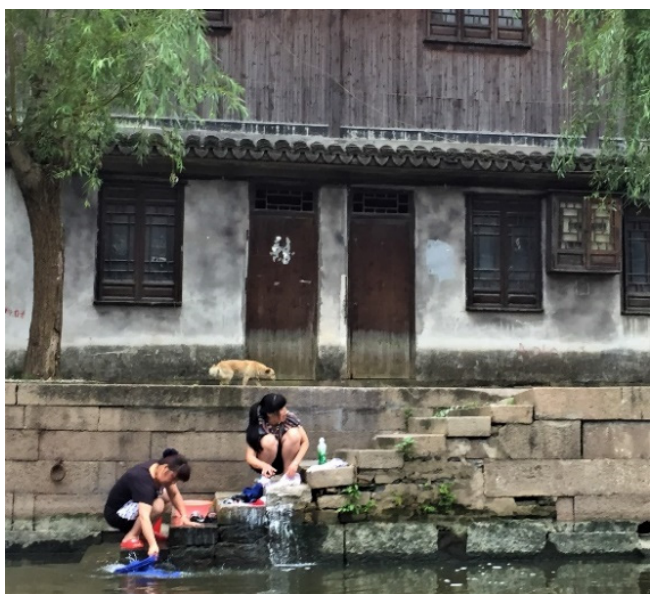

(b)

Figure 16. (a) Canal fronts have stone revetments and regularly-placed flights of stone stairs, Nanxun, 2016 (photo by the author). (b) Residents doing their washing along the canal, Nanxun, 2016 (photo by the author).

Rivers and canals may be flanked by streets on both sides or only on one, and may be crossed by bridges and overlooked by balconies, while the water-side streets may be covered by porticoes or overhanging houses, may host trees and can open out to small public spaces, often adjacent to a bridge (Figure 17).
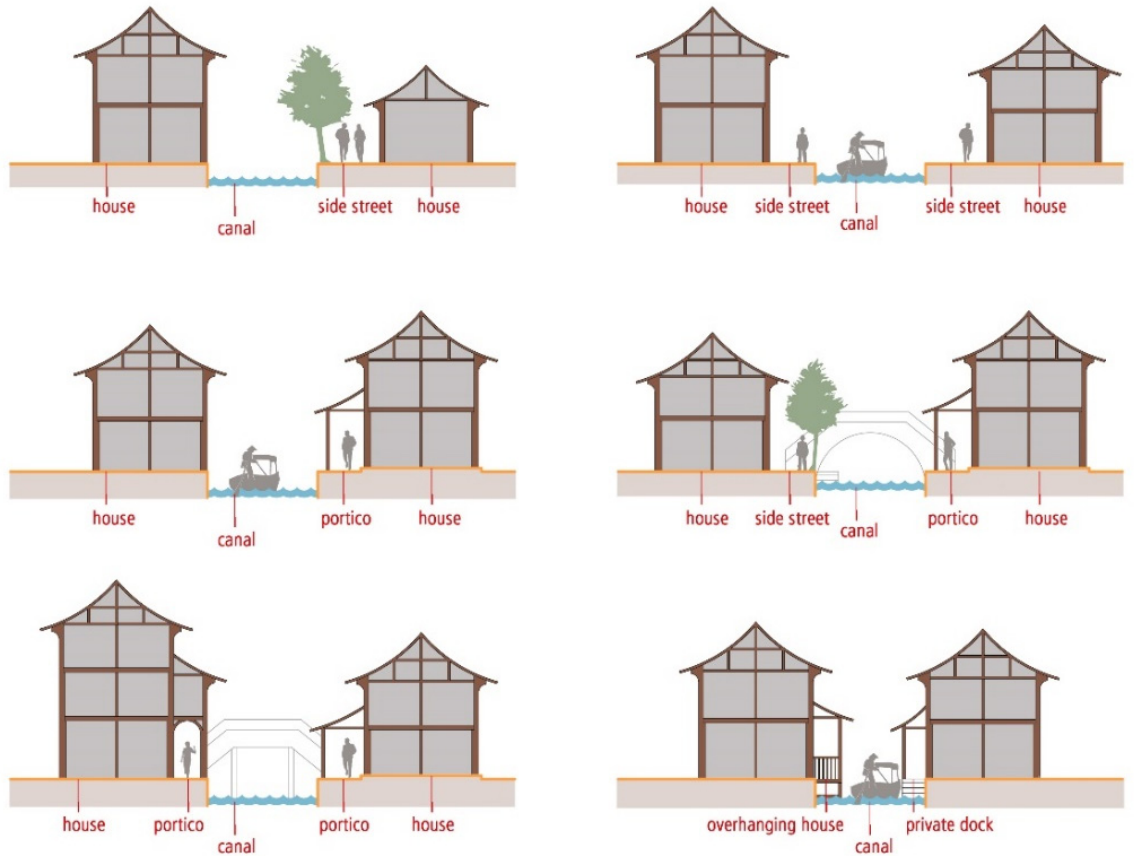

Figure 17. Diagram illustrating the different patterns of the street-building-canal interrelationship structuring the urban form of the water towns south of the Yangtze river (elaborated by Paola Brunori).

Bridges not only represent crossing points, but, based on this, they are also important focal points of city life. This is the case with the five-arched, 70 meter long, limestone bridge of Zhujiajiao (Figure 18), crossing over the Caogang river, which was built in 1571 [4] (p. 109). In the daytime, the two bridgeheads were, and still are, noisy business locations for vendors and customers, while in the evening they serve as gathering places for locals. 


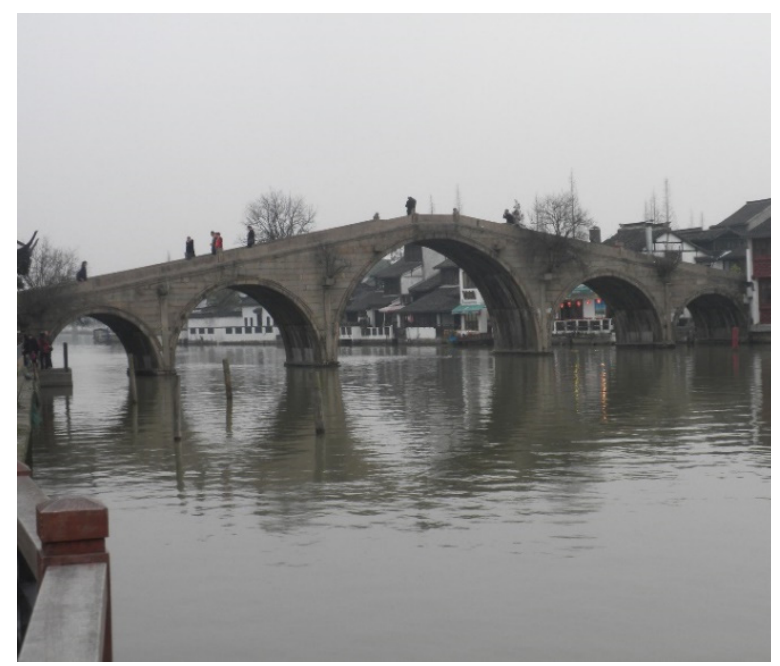

Figure 18. Five-arched limestone bridge, Zhujiajiao, 2015 (photo by the author).

Stone or timber, flat or arched, with one or many more arches, covered or not, straight or zig-zag, connecting two or three banks, processional or commercial, the bridges are the real protagonists of water towns (Figure 19a-c). Covered, timber bridges or "corridor bridges", were quite common in old times, offering protection from bad weather while crossing the water or functioning as places for a brief rest and socialising (Figure 20). Most have been destroyed, although a few were recently rebuilt—such as the Huiming bridge in Zhujiajiao, rebuilt in 1996 [4] (p. 110). Their location was not only functional, but also symbolic. Thus, imposing bridges were often situated next to important temples or mansions (Figure 21a), playing a central role (similar to that of piazzas in Renaissance Italy), in public and religious life, as in the case of the Zhenze processional bridge (Figure 21b).

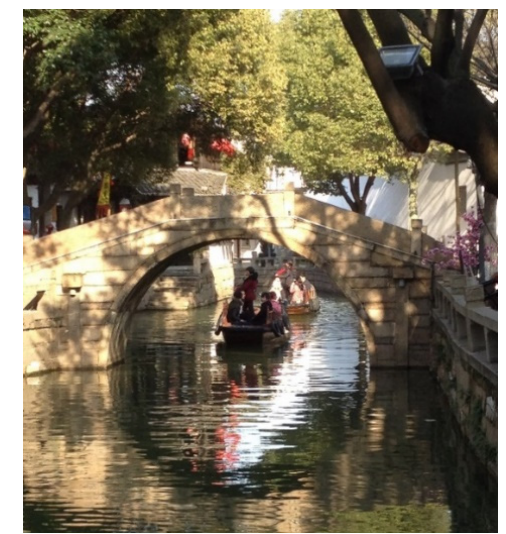

(a)

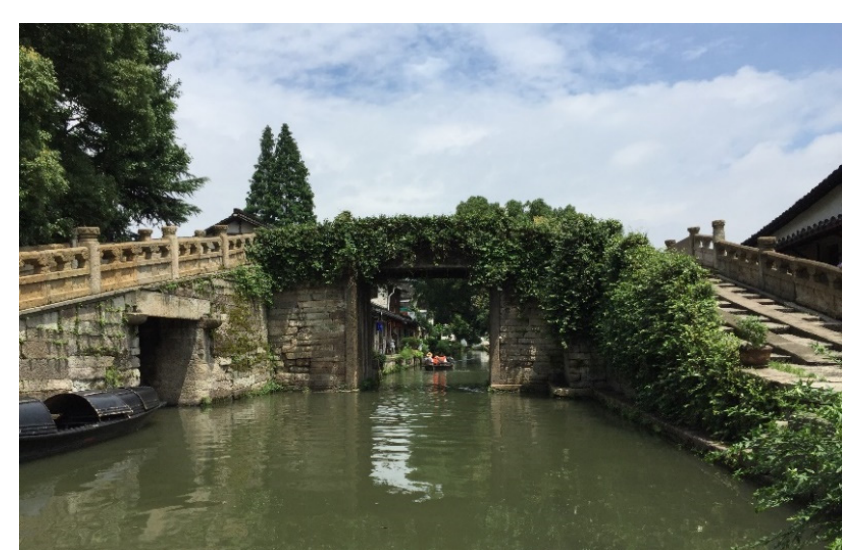

(b)

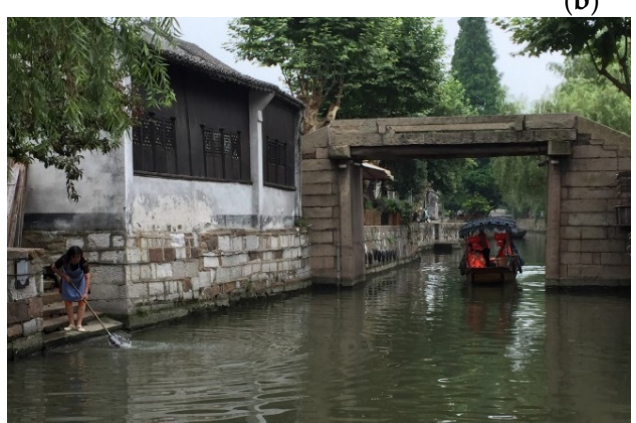

(c)

Figure 19. (a) Single arched bridge, Tongli, 2017 (photo by the author). (b) Bazi bridge, connecting three banks, Shaoxing, 2016 (photo by the author). (c) Flat bridge, Nanxun, 2016 (photo by the author). 


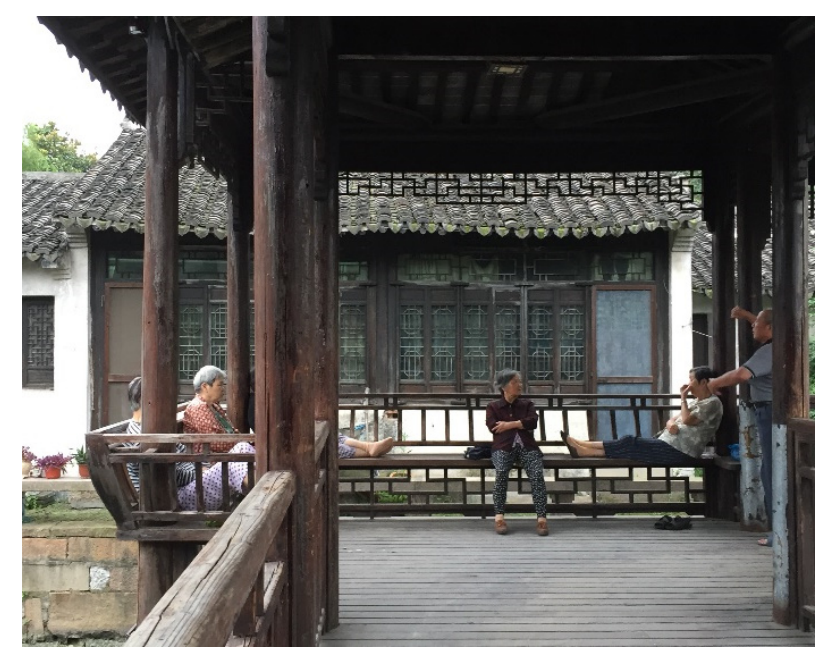

Figure 20. Wooden covered or "corridor bridge" as place of socialisation, Nanxun, 2016, (photo by the author).

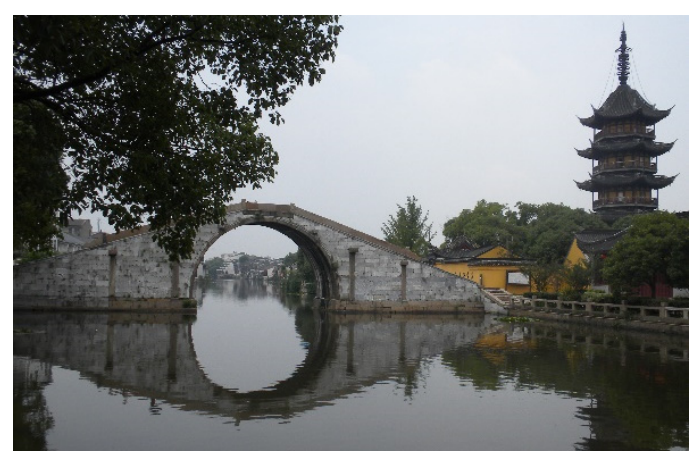

(a)

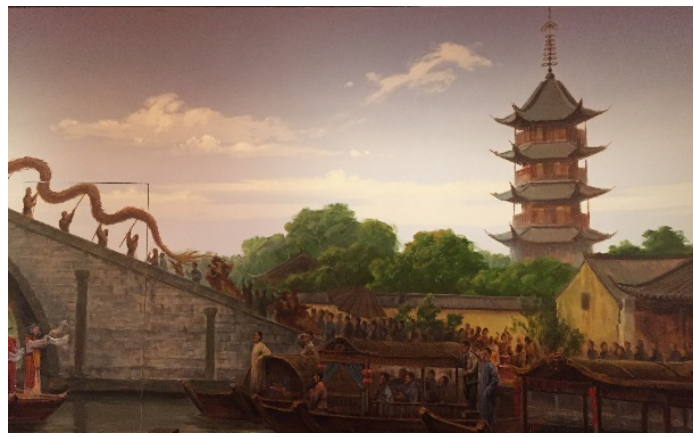

(b)

Figure 21. (a,b) Bridge next to a temple, Zhenze, 2017. It plays an important role in religious life, as a processional bridge (photos by the author).

\section{The Conservation of Historic Water Towns}

\subsection{Urban Conservation in China}

Since the economic reform of 1978, China has been experiencing a rapid urbanisation process accompanied by the privatisation of land use rights (rather than land ownership) $[18,19]$, which has greatly favored the destruction, for redevelopment purposes, of old city cores and small towns [20-22].

In 1982, ${ }^{6}$ the first Law of the People's Republic of China [23,24] on the Protection of Cultural Relics (Zhonghua Renmin Gongheguo Wewu Baohufa), was launched by the State Council; ten years later, in 1992, regulations for its implementation were issued, providing technical support [25]. Revised in 1991 and 2002, this law became the basis for conservation policies both nationally and locally. In this context, conservation was gradually extended from the preservation of individual buildings—-that is, of "monuments and sites" - so as to encompass a broader scale relevant to "Historical traditional street districts" (1985-1986), and the whole historic built environment, introducing the category of "Historic and cultural cities, towns and villages" (2003-2008) [26] (pp. 20-32), [27].

6 Awareness of the value of conservation research and legislation emerged in China in the 1920s. The Research Institute of Archaeology (Kaoguxue Yanjiusuo), is perhaps the earliest organisation to carry out research on conservation of the built environment, and was established in Yanjing University in 1922. But this tradition was greatly lost with the advent of Socialist China and more particularly with the 10 years of the cultural revolution and the movement for "destroying the old four" [23]. 
This conceptual evolution of urban conservation is clearly reflected in the List of Precious Historic Cities (Lishi Wenhua Mingcheng), introduced in 1982 by the State Council, which represents the second major urban conservation tool in China. The list initially comprised 24 cities, including Beijing, Luoyang and Xian, selected among those " ... that have reserved abundant cultural relics ... " [28] (p. 8). This loose definition of urban heritage as a sum of individual buildings was superseded in 1986, when a second list of 38 cities was formulated on the basis of local historical-cultural zones, and not simply historic buildings. In 1994, the Guideline for Preparing Conservation Plans for Historical-Cultural Famous Cities, prepared by the Ministry of Construction and the Bureau of Cultural Relics, which emphasised an area-based conservation plan, was mirrored in the new group of 37 cities added to the list that same year. The final step of this conceptual evolution was reached in 2008, when the State Council adopted the Regulation on the Protection of Famous Historical and Cultural Cities, Towns and Villages, promulgated in 2005 by the Ministry of Construction, in which both the content and the objective of urban conservation were clearly addressed. The Regulation identified the legal responsibilities and the procedures to be followed, the support measures and the sanctions, giving, in a nutshell, legal protection to the category of "Historic cities, towns and villages" [16]. Since 1982, therefore, a significant number of historic districts, cities and small towns have been listed and protected. As of 2014, there were 125 cities on the list [16] (p. 457). According to central government guidelines, conservation aims to "sustain and preserve traditional characteristics with appropriate urban development" [29] (p. 411), which means that conservation and development should be mutually supportive, while the decision of what represents tradition and built heritage, and how it should be preserved, interpreted or reutilised is entrusted to local authorities, architects and planners. ${ }^{7}$

In fact, while the protection of "monuments and sites" depends on the National Office of Cultural Affairs, the protection of historic cities depends on the Ministry of Construction and Urban and Rural Development (MOHURD). It is the planners' responsibility, therefore, to define the "conservation area" boundaries and the actions to be undertaken for the conservation and development of the protected area. Practically speaking, urban planning (according to the Guideline and Regulation mentioned above) has the following roles: it is the tool that defines the perimeter of the conservation area and the way it must be protected; it identifies the relationship between conservation and development; and it protects heritage, while favouring economic and social development and aiming to better the conditions of life and work of the inhabitants. In this context, there are three major aspects urban conservation should address: "the protection of heritage buildings and ensembles; the conservation of the configurations of urban texture and their characteristics; the transmission and development of note-worthy elements of cultural tradition" [30] (p. 10).

As Whitehand and Gu [23] (pp. 648-649) have already highlighted, the incorporation of urban conservation in urban planning developments in China has favoured a top down approach that often fostered land-use planning procedures as urban conservation methods. In parallel, the limited research on Chinese urban history and conservation from a methodological and theoretical viewpoint $[16,31]$ has favored a dependency on Western methods and trends. Notwithstanding the recent increasing attention drawn to heritage conservation [32,33], Chinese urban conservation still lacks a systematic analytical approach to its traditional settlements. This paper highlights these issues, through the water towns case study and the critical assessment of Ruan Yisan's conservation planning.

7 In fact, many academics and teaching staff from architecture and urban planning schools in China are actively involved in conservation planning practice and theoretical research, as Professor Ruan Yisan, on whose professional work this paper is focusing. Regarding his theoretical research see: Wang, J., Ruan, Y.S. Historic City Conservation Theory (in Chinese), Tongji University Press: Shanghai, China, 1999; Ruan, Y.S., Lin, L. Authenticity in Relation to the Conservation of Cultural Heritage, in Urban Heritage Conservation, edited by College of Architecture \& Urban Planning Tongji University, China Architecture \& Building Press: Beijing, China, 2010, pp. 49-61; Shao, Y., Ruan Y.S. Evolution and Character of the Historical and Cultural Heritage Preservation Law in France, in Urban Heritage Conservation, edited by College of Architecture \& Urban Planning Tongji University, China Architecture \& Building Press: Beijing, China, 2010, pp. 143-152 [28]. 


\subsection{Water Towns Conservation Planning and the Role of Ruan Yisan}

Professor Ruan Yisan is one of the first (if not the first) planner [4,7,34], to study and get involved with protecting and planning historic water towns by assisting local residents, as he himself put it, "in renovation, and developing tourism, which help the historical value of ancient towns reappear, develop the local economy and improve people's living standard" since 1986 [4] (p. 173). The water towns that he planned to the south of the Yangtze river, according to the chronological period of his involvement, are as follows (Figure 22): in the second half of the 1980s, Zhouzhuang, Tongli, Luzhi, Nanxun, Jiaxing, Wuzhen and Xitang; in the 1990s, Zhujiajiao, Xinchang, Anchang, Longmen, Qianton and Mudu.

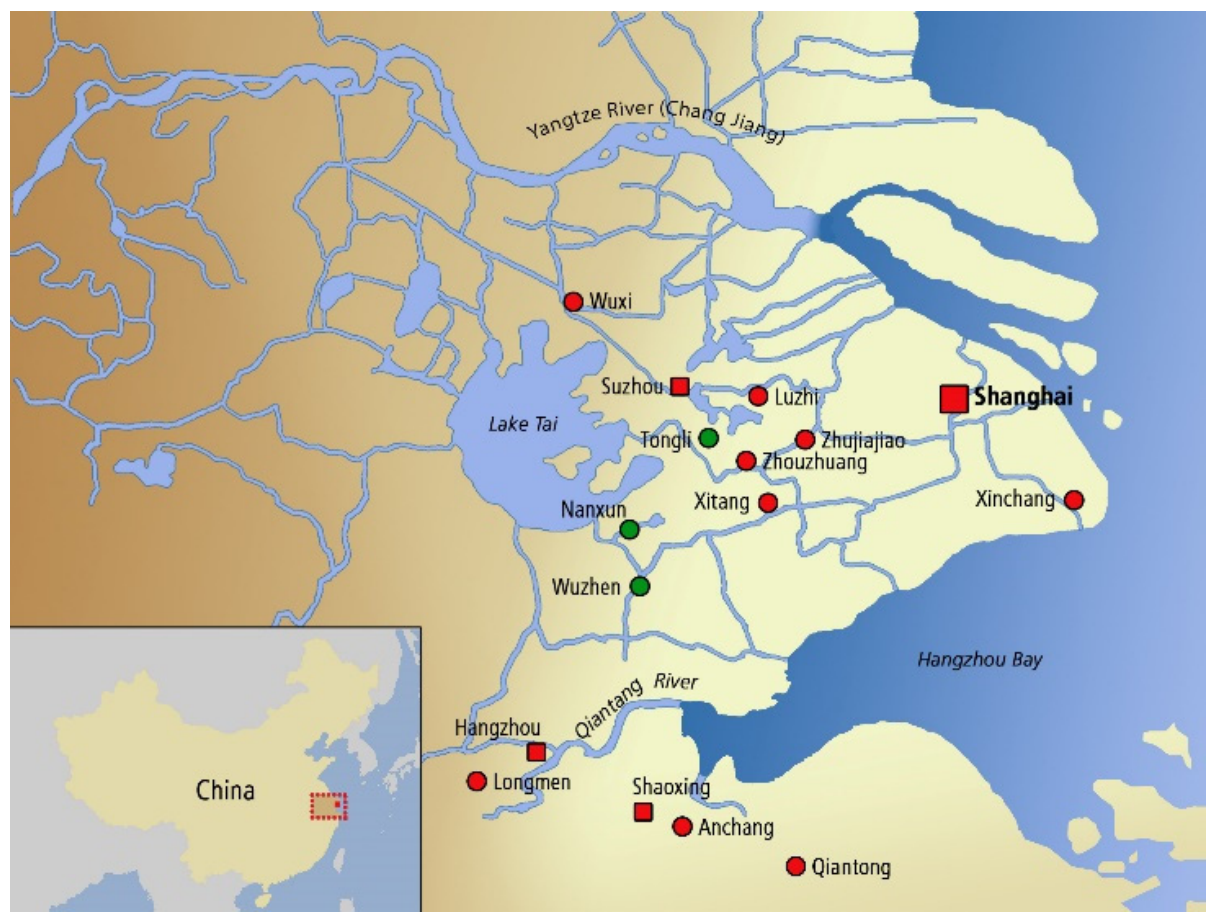

Figure 22. Map of the water towns south of the Yangtze river planned by Professor Ruan Yisan (re-elaborated by Paola Brunori from [4] p. 179).

"The large-scale conservation planning of the historic water towns at the mouth of the Yangtze River sets an important milestone in the protection of living cultural landscapes." These words opened the text of the UNESCO Asia-Pacific Heritage Award of Distinction for the cultural heritage conservation work Professor Ruan and his Tongji University team had undertaken in six of the water towns south of the Yangtze river-an award he received in $2003^{8}$ [11,35]. It goes on:

"The comprehensive approach adopted by the project allows for thorough understanding and interpretation of the area's natural and cultural heritage at both the local and regional levels. Operating with an overall conservation masterplan, a clear policy framework, and sound methodology, the project restores the authentic significance and function of the towns' waterways and historic settlements, while accommodating modern needs and anticipated growth. Major investments by the

8 According to Maylis Bellocq these six small historic water towns "had submitted a joint application to be listed as a world heritage site and were included in the first national list of historic towns and are, since 2008, subject to the Regulation for the Protection of Historic Cities, Towns and Villages (Lishi Wenhua Mingcheng)." [11] (p. 5). According to Alain Marinos "La petite ville de Tongli, qui fait partie des six villes d'eau du Jiangnan pour lesquelles était projetée une demande d'inscription sur la liste du patrimoine mondial de l'UNESCO, a été retenue. Les réalisations entreprises ont été primées à trois reprises, par le ministère chinois de la Construction en 2002 et par l'UNESCO dans la région Asie-Pacifique en 2003 et 2007" [35] (p. 19). 
government for public works and by residents for individual structures creates a commendable model of sustainable long-term public-private partnership. The ambitious scope of the project promises to have a major impact on shaping future developments in the towns as well as conservation practice throughout China.". [4] (p. 15)

Ruan Yisan, who also pioneered the conservation of other historic cities such as Pingyao [36,37] (designated a National Historical and Cultural City by the State Council in 1986 and a UNESCO WHS in 1997 [38]), has worked on more than two hundred conservation plans for cities and heritage sites all over China, coordinating an entire pool of Chinese experts from Tongji University. He has been professor and Dean of the School of Architecture and Urban Planning of Tongii University (Shanghai) and, since 1998, as Director of the National Research Centre of Historic Cities (also based at Tongji University), has initiated a long term cooperation with France and specifically with the Observatoire de l'architecture de la Chine contemporaine, nowadays attached to the Cité de l'architecture et du patrimoine [35] (p. 17). He is now chairman of the Ruan Yisan Heritage Foundation (which he founded in 2006) [39], and was recently awarded the Henry Hope Reed Award of the University of Notre Dame, USA [40].

According to Professor Ruan, five aspects are necessary for the implementation of protection and planning of water towns. They represent the synthesis of his long experience of water town conservation, as initiated in 1986 with the master plan and town protection plan of Zhouzhuang [11] (p. 6), and have been briefly summarised by him [4] (pp. 175-177) as follows:

- $\quad$ Raise local people's awareness;

- $\quad$ Focus on protection through development, putting forward the policy of "protecting ancient towns, constructing new zones, developing town's economies, and opening up tourism" [4] (p. 175);

- $\quad$ Proceed differently in response to different situations, which implies defining differentiated protection measures according to the different protection class that cultural heritage and sites belong to inside and outside the ancient towns;

- Manage protection. Record and map existing towns in order to plan their protection, transformation, necessary reconstruction and reuse. "When planning, we should pay special attention to the inheritance and promotion of traditional culture such as traditional customs, products, handicrafts, snacks and dishes, literature and arts, etc." [4] (p. 177)

- Develop tourism accordingly. "The beautiful look with the special water town features, the plain and pure folkways and people, traditional dishes and snacks and the rich and colourful crafts the ancient towns possess are tourist sources people living long in cities crave for. On the one hand, we should enhance the ancient towns' popularity via media's propaganda; on the other hand, we established places in ancient towns and suitable places for serving tourists so that we could meet the tourists' demands for 'eating, living, walking, visiting, shopping and entertaining'".

According to Ruan's writings and planning: "The ancient towns would have developed tourism gradually which would have increased people's income and also reinforced the protective potentiality more" [4] (p. 177).

A closer look at three of the water towns planned by Ruan Yisan helps to provide a better understanding of the impact of his conservation planning approach, and the opportunities it offered alongside the risks that it introduced.

\section{Historic Water Towns Conservation and Tourist Development}

\subsection{Nanxun, Tongli and Wuzhen-Three Cases Representing Different Implementations of Ruan Yisan's Conservation Planning Approach}

Nanxun's history is closely related to the silk market and industry, which started growing in the 16th century, reaching its peak in the 19th and early 20th centuries, when the town had largely expanded with big mansions, fashion stores, silk shops and piers, equalling in prosperity the big cities 
of Suzhou and Hangzhou. Nanxun's silk production and its exquisite quality were closely dependent on the clear and abundant waters of the region (Figure 23). The town housed a very large group of silk merchants, who greatly influenced the economy and society of the area up to the 1930s crisis, leaving evidence of their wealth, culture and refined customs: in their mansions, such as the Zhang Shiming former residence (1871-1927), combining Chinese and European architectural ornamentation (Figure 24) and covering an area of around $5000 \mathrm{~m}^{2}$ with hundreds of rooms; in their gardens, such as the Classical Little Lotus villa (1885-1924) of 1.8 hectares (Figure 25a,b); in libraries, as the Jiaye Library, occupying an area of $13,000 \mathrm{~m}^{2}$ and now housing 130,000 volumes and 30,000 woodcut editions; and in architectural urban complexes, such as the so called "Hundred-Room Residence" (Figure 26). This continuous uninterrupted line of one- to two-storey, whitewashed folk houses with arched porticoes, black roof tiles and brick-stepped, gabled, intermittent firewalls, which stretches along both sides of the narrow winding river, creating a harmonious and unique atmosphere, gives evidence-even in folk residences—of an urban design intervention (probably in the 16th century) [41-44].

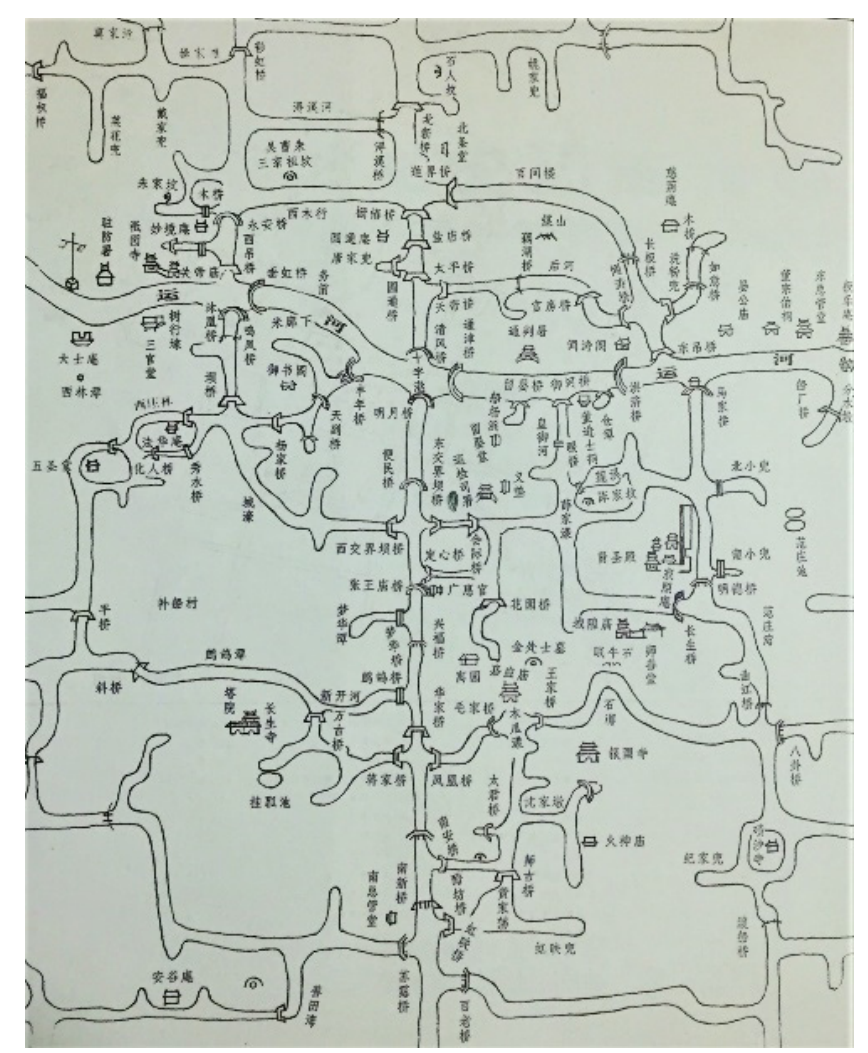

Figure 23. Design from Wāng Yuēzhēn's book "History of Nanxun District", 8th year of the kingdom of emperor Xianfeng, Qing dynasty. 


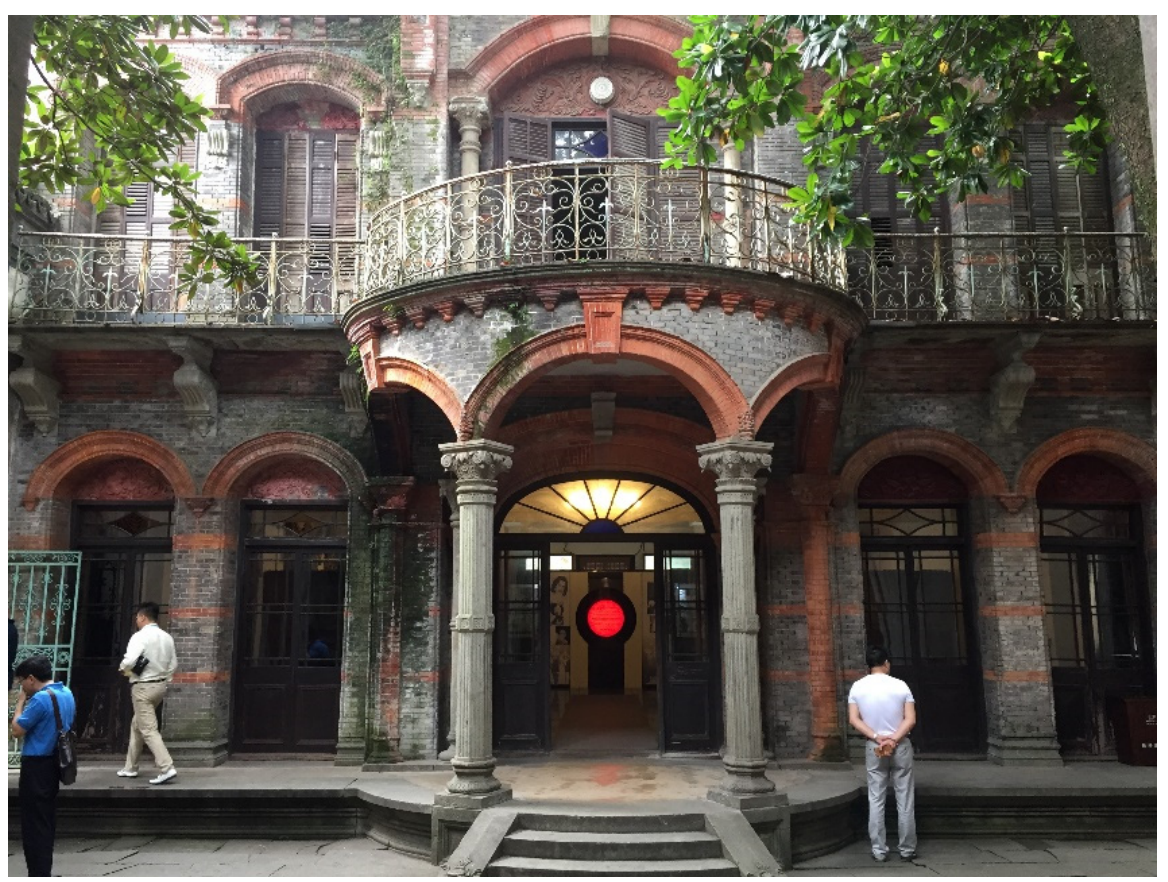

Figure 24. The Zhang Shiming former residence (1871-1927), combining Chinese and European architectural ornamentation, Nanxun, 2016 (photo by the author).

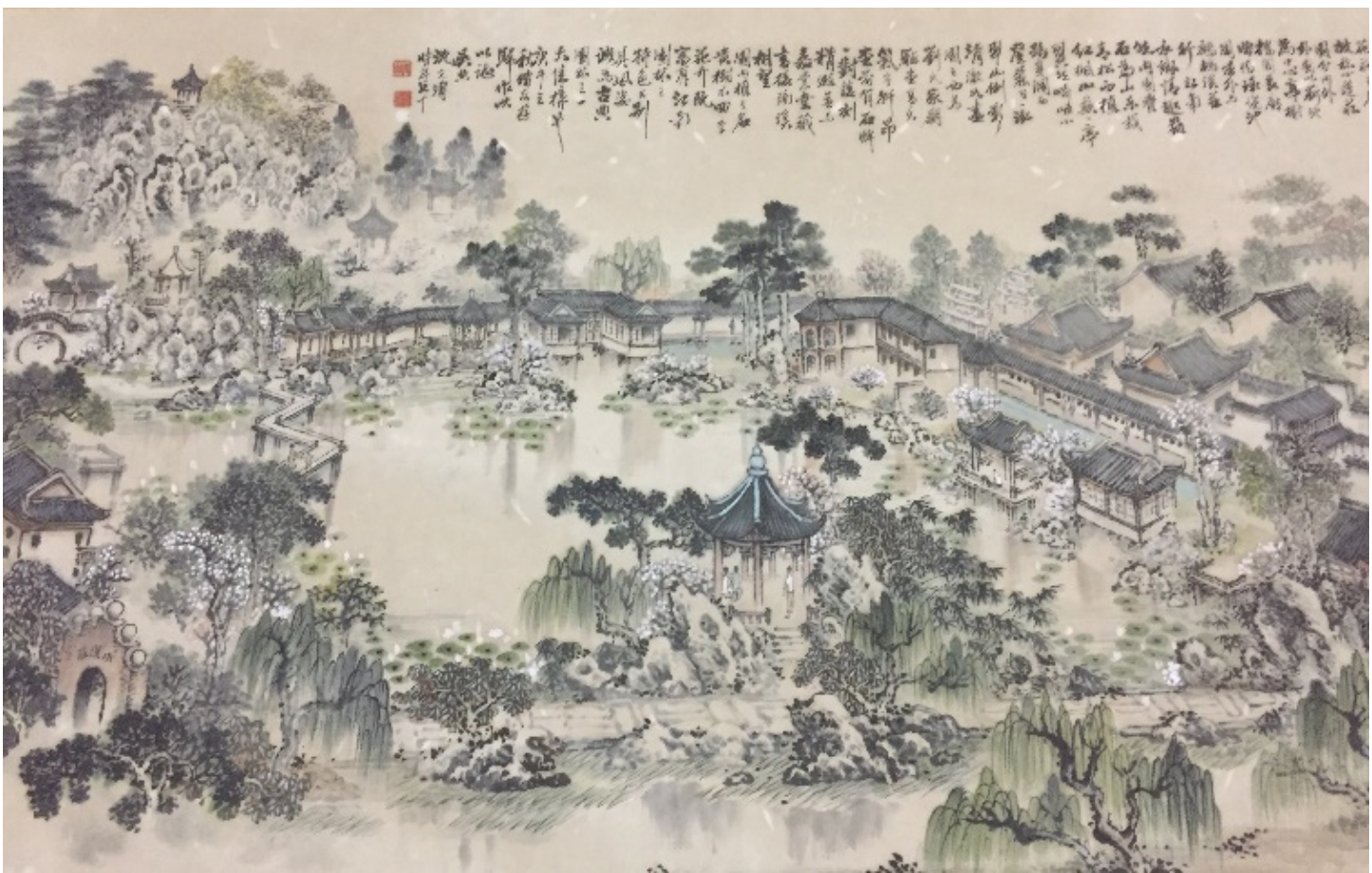

(a)

Figure 25. Cont. 


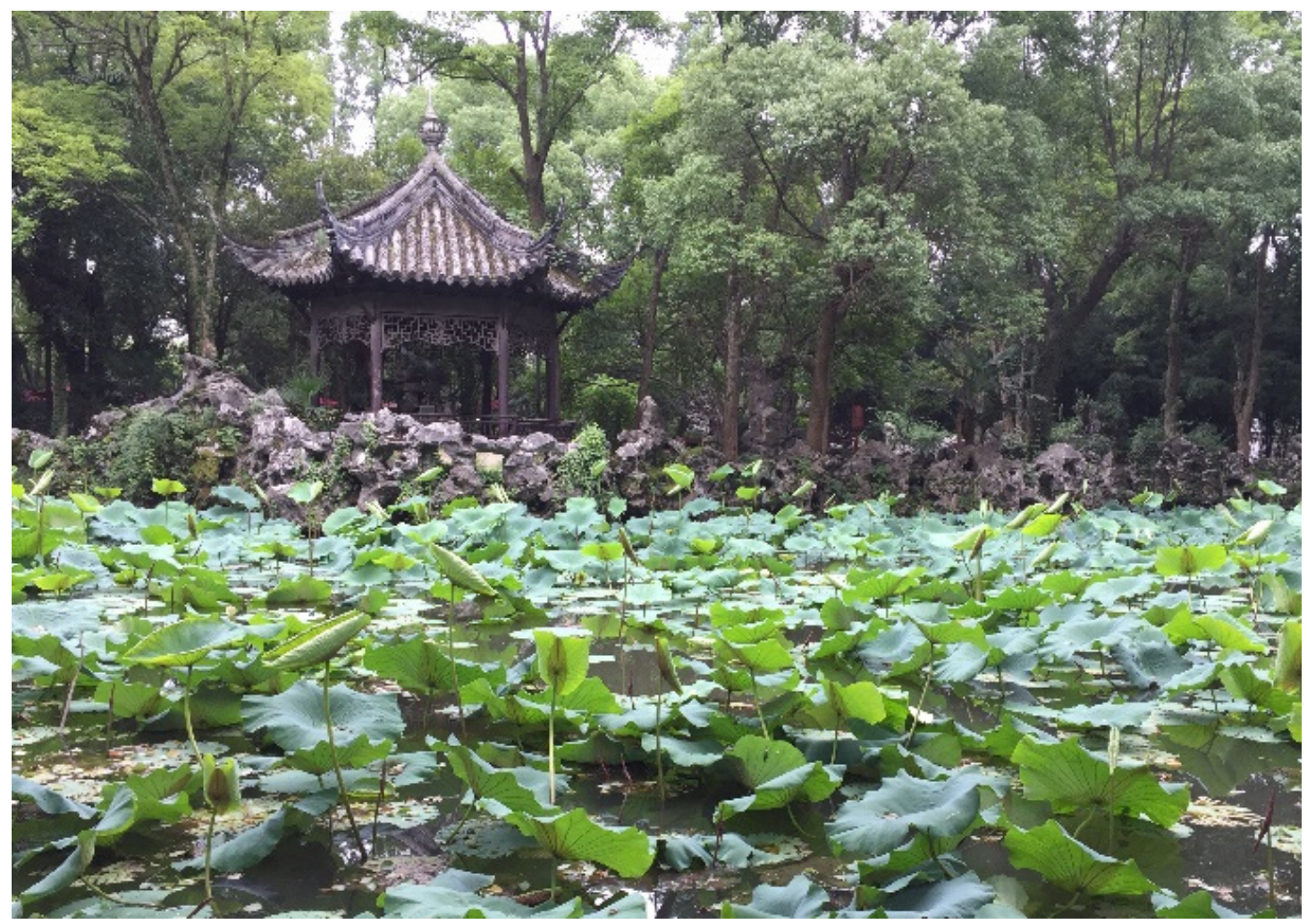

(b)

Figure 25. (a) Design of the Classical Little Lotus villa (1885-1924), Nanxun. (b) Pavilion of the villa, Nanxun, 2016 (photo by the author).

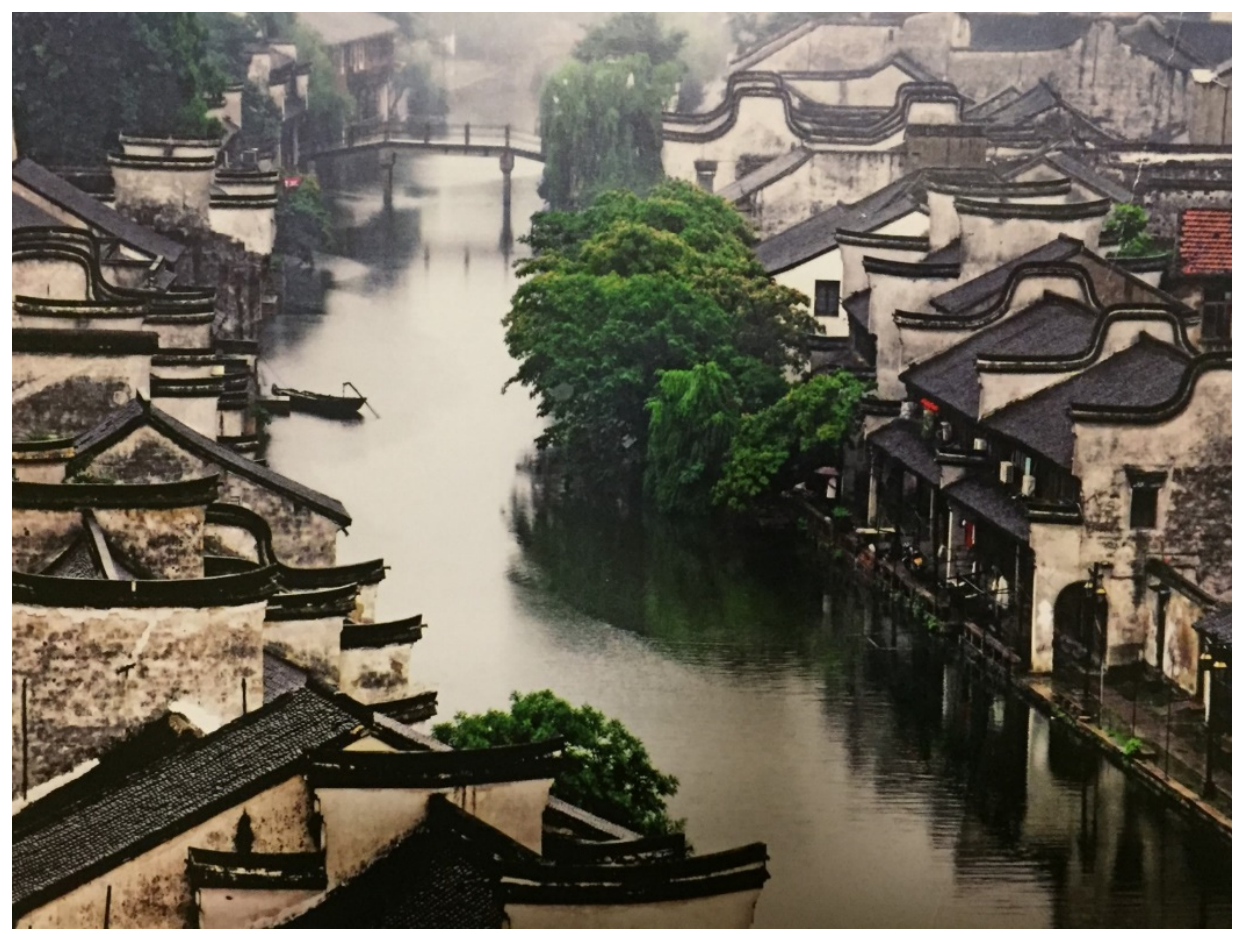

Figure 26. The urban complex known as the "Hundred-Room Residence", Nanxun, 2017.

Nanxun was one of the second group of towns added to the list of Famous Historical and Cultural Cities to be preserved in 1986, and great care has been taken in its conservation plan, undertaken by Professor Ruan, which extended over five years [45]. Nowadays, although tourist access to the city's 
historical core is by entrance ticket, with tourist attractions and creative industries, boat itineraries and special cultural events representing local customs and so on [46-48], the city remains relatively authentic—although only after dusk, as even the local tourist agency comments:

"Unlike some other ancient water towns, Nanxun is still inhabited. Furthermore, it is free to visit the town after 17:00 each day. Although tourist attractions and most shops will be closed after 17:00, tourists can still take a stroll through the town and observe the local people's life. In some respects, the authentic town only emerges after 17:00 anyway.". [49]

The old historic town of Tongli, 0.68 square kilometres in size (only $90 \mathrm{~km}$ away from Shanghai and about $20 \mathrm{~km}$ from Suzhou, to which it is nowadays linked by metro), was once famed for its achievements in the imperial examinations and has produced famous Confucians and notables, as recorded by more than 40 stone tablets around the city and the numerous streets named after officials' titles. The town's isolation, becoming accessible by car only in the 1980s, maintained its ancient morphology and scale intact, characterised by the traditional houses dating back to the Ming and Qing dynasties densely settled on both sides of the banks (Figure 27), the winding alleys and the unaltered street network, paved with pebble stones and interlinked by numerous bridges [50,51]. Once again, it was Professor Ruan who prepared the city's conservation plan in the late 1980s, according to which the buildings built during the Ming and Qing dynasties covered an area of 40,000 square meters [11]. Some of these buildings were restored and opened to visitors, as was the case of the Gengle and Tuisi residences (the latter inscribed in the world heritage list along with the famous Suzhou garden residences), but most of them remained initially inhabited.

The case of the Tuisi residence and its garden (Figure 28) is quite representative of how restoration interventions were implemented both in Tongli and elsewhere. The documentation collected by Maylis Bellocq shows that the residence "after being requisitioned by the local authorities in 1949, was occupied by a transistor factory, a chemical warehouse, a canteen, an infants' school, a peasant workers' dormitory, a cotton mill, and a union office" [52] (p. 24]. Identified as an important heritage site in which to invest efforts and money, it was "restored", and in 1997-2000 it was nominated as a UNESCO world heritage site. However, neither does its restoration show any traces of these previous transformations, nor do the building's guidebooks mention anything about its recent history. "Amnesia" has veiled this building's Socialist past [52], and it is reasonable to think that all the functional changes the building has gone through would have seriously damaged it. Therefore, it may be more appropriate to use other terms, such as reconstruction and renovation, rather than "restoration", to describe such interventions. A similar path has been followed by most of the renovation works applied to folk houses, and generally to the built fabric. In fact, hundreds of medium size residences of merchants or wealthy families with several successive courtyards, which were expropriated in the 1950s and subdivided for several poor families [7], have been "restored", reviving the hypothetical original state of the building [16], preferably of the Qing dynasty [53], and neglecting all transformations and memories of the Socialist period.

In the conservation of Tongli, Professor Ruan apparently deployed the same policy originally tried out in Zhouzhuang - that is, "to fully utilise the human, cultural and historical resources in order to reinforce the town's cultural characteristics for tourist purposes" [30] (p. 74).

Wuzhen was famous as a silk town, but also for its dye houses and wine workshops. It has a rich built heritage going back to the Song and Qing dynasties, and its waterfront houses have a special character because they are supported by log piles or stone pillars overhanging the river (Figure 29). Ruan Yisan describes in his Water Towns [4] (pp. 54-55), [54] how the town's political leaders approached him in 1998, following the success of his planning in Zhouzhuang and Tongli, requesting his planning consultancy expertise for Wuzhen [30] (pp. 70-84). His plan was implemented in 1999, and the small town, situated along the Grand Canal, crossed by narrow waterways and adorned by numerous old stone bridges, opened to visitors in 2001. Ronald Knapp, who probably visited it in 2002-2003, described it as follows: 
"Unlike some of the better known water towns, little of Wuzhen has been restored, yet many old buildings remain in a noteworthy state of preservation. Life in Wuzhen is much as it was in the past, with remarkably few buildings specifically serving tourists. Walking along any of the narrow lanes, one can easily glimpse the rhythms of daily life: people carting fresh water, cooking meals, tending to young children, and playing mah-jong. Local workshops continue to make wine and homespun cotton.". [55] (p. 127)

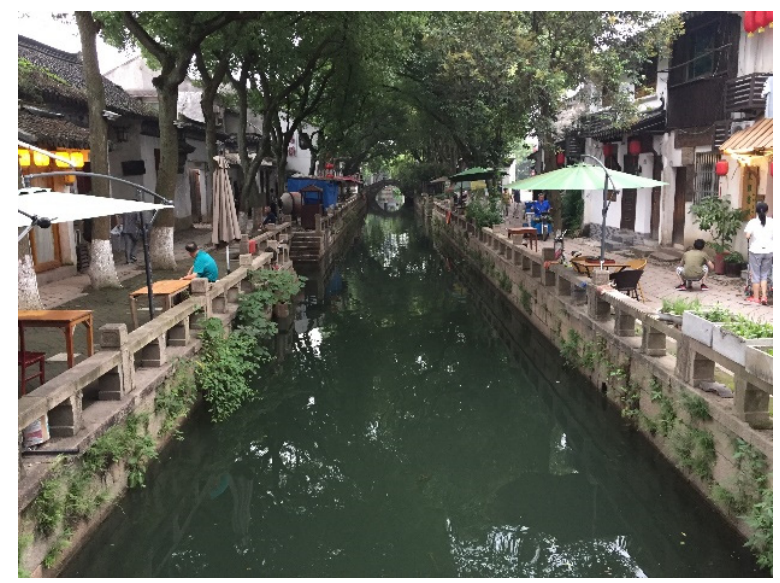

Figure 27. Traditional houses densely settled on both sides of canal banks, Tongli, 2017 (photo by the author).

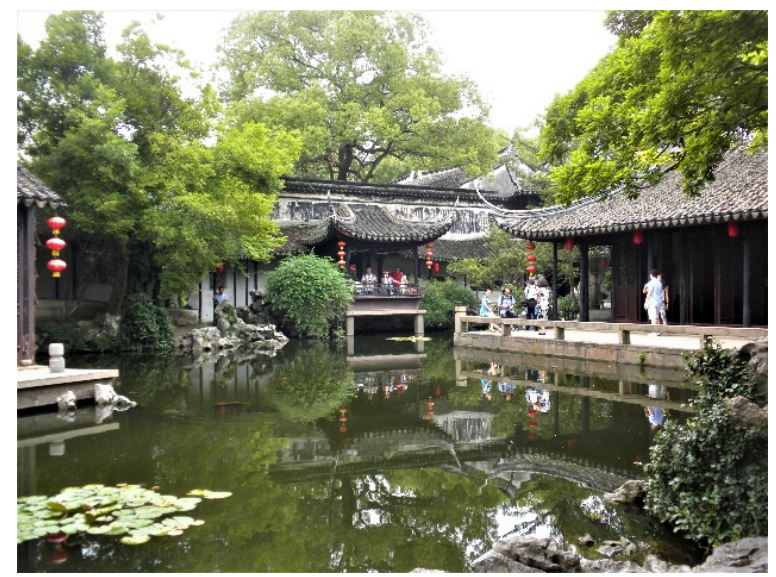

Figure 28. Tuisi residence and garden, UNESCO site, Tongli, 2017 (photo by the author).

However, the strong local leadership that set up the Wuzhen Protection and Tourism Developments Administrative Committee [56] managed to turn the historic area of Wuzhen, 1.3 square kilometres in size, "from a quiet and unheard-of village in the north of Zhejiang, into a well-renowned, world class town for tourists! Since 1999 the city has obtained innumerable honors and has gone through years of prosperity". In these words, the local administrators reported to us proudly their achievements in our official visit in 2015 [12]. Through population displacement and the musealisation of the entire historic town (Figure 30), the Wuzhen administration has managed to cancel any trace of Knapp's description. 


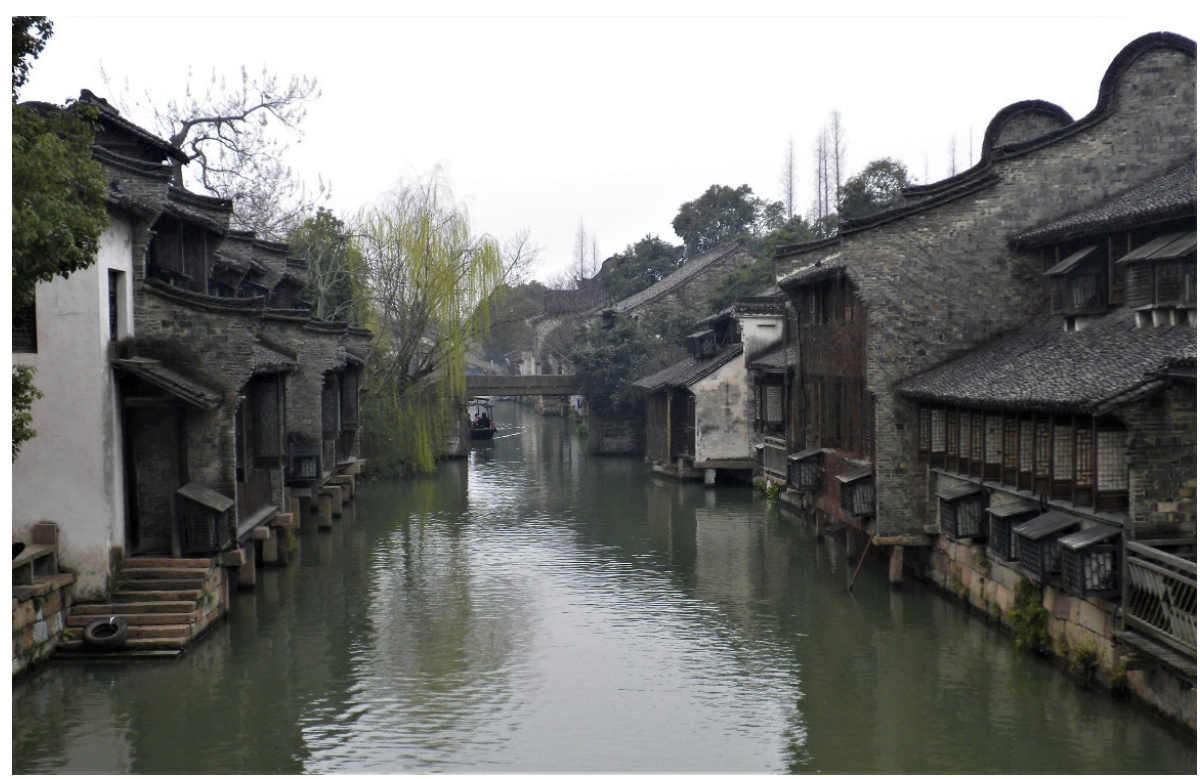

Figure 29. Characteristic waterfront houses of Wuzhen, overhanging the canals and supported by log piles or stone pillars (photo by the author, 2015).

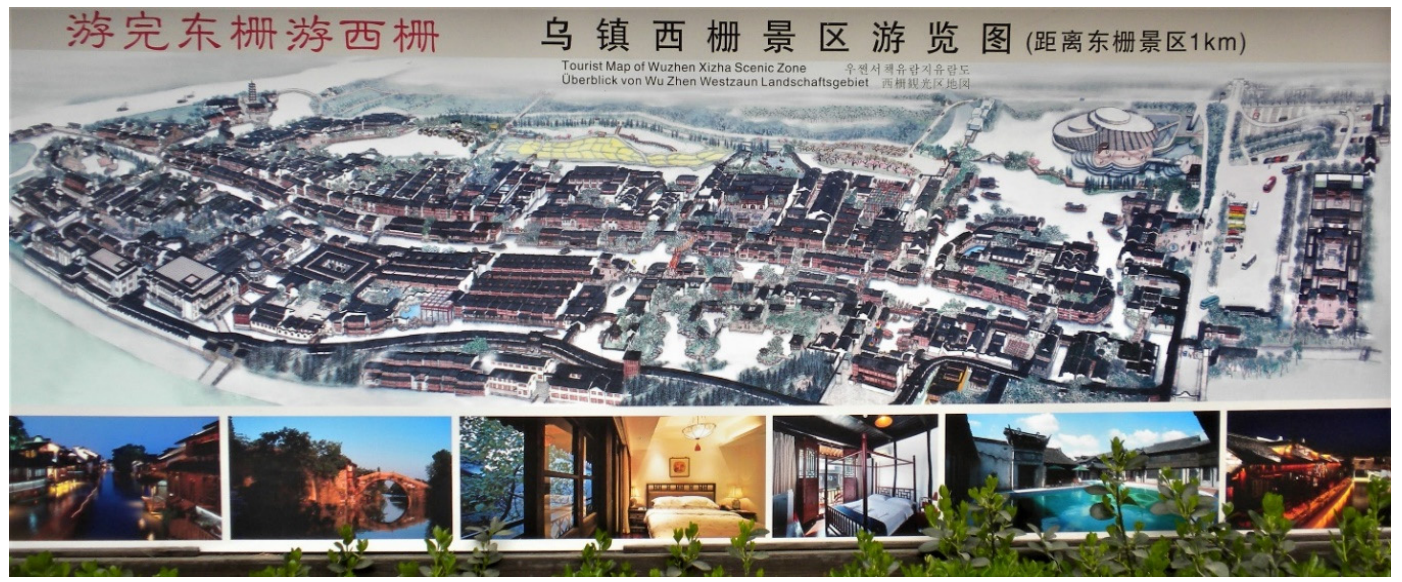

Figure 30. Wuzhen tourist map: on the right hand side, the town's entrance gate and ticket office, next to the parking lot (photo by the author, 2015).

\subsection{Conservation and Tourism: a Difficult Marriage}

It is undeniable that Ruan Yisan's plans of the 1980s and 1990s gave a new dignity to the historic water towns, which, up to that point, had existed in a state of decay and abandonment, without appropriate infrastructure (sewage, electricity, gas or private toilets, etc.), without financial resources to promote any kind of restoration and with no public appreciation for their heritage. He describes the meetings he organised with academics, professionals, political and local authorities to promote his planning work and attain state approval and financial support for its implementation, and the way he tried to find support by increasing local citizens' awareness [30] (pp. 110-112), [11] (pp. 6-8). In parallel, the central government's decision to include heritage tourism as an economic resource in the seventh Five-Year Plan (1986-1990) helped to overcome the deeply rooted belief that heritage protection was synonym of backwardness and that industrialisation was the only way to modernisation [7] (p. 5).

By the end of the 1980s, his work had gradually started to come to fruition and he was commissioned to take on more plans. The 1990s was the decade in which heritage conservation at urban scale was affirmed, and also when it was consolidated at the legal level, and the tourist industry was accepted as a new economic resource, able not only to recover the costs of new conservation interventions, but also 
to increase local growth [11] (pp. 8-9). With the advent of the new millennium, however, internal mass tourism grew exponentially and the newly conserved water towns started to experience a flux of tourists over the weekends, soon becoming overcrowded (Figure 31). The ideal tourist flow, capable of being supported by the fragile urban fabric of a water town like Zhouzhuang, according to Professor Ruan's planning evaluations, would have been 600,000 visitors annually; by 2002, however, the town was already recording 2.63 million entrance tickets annually, while in the high season, up to 40,000 people visited it daily. In 2005, the tourist flows in Tongli reached 2.2 million (Figure 32), and Wuzhen also had more than 2 million visitors in 2007. This number almost doubled the year after, in 2008 [30] (p. 81), and had reached 7 million visitors by 2014. According to the perspectives of the 11th Five-Year Plan (2006-2010), tourism should have represented 7\% of the GDP, with the number of domestic tourists estimated at 1.78 billion in 2010 and 2.6 billion in 2015 [57] (p. 9).

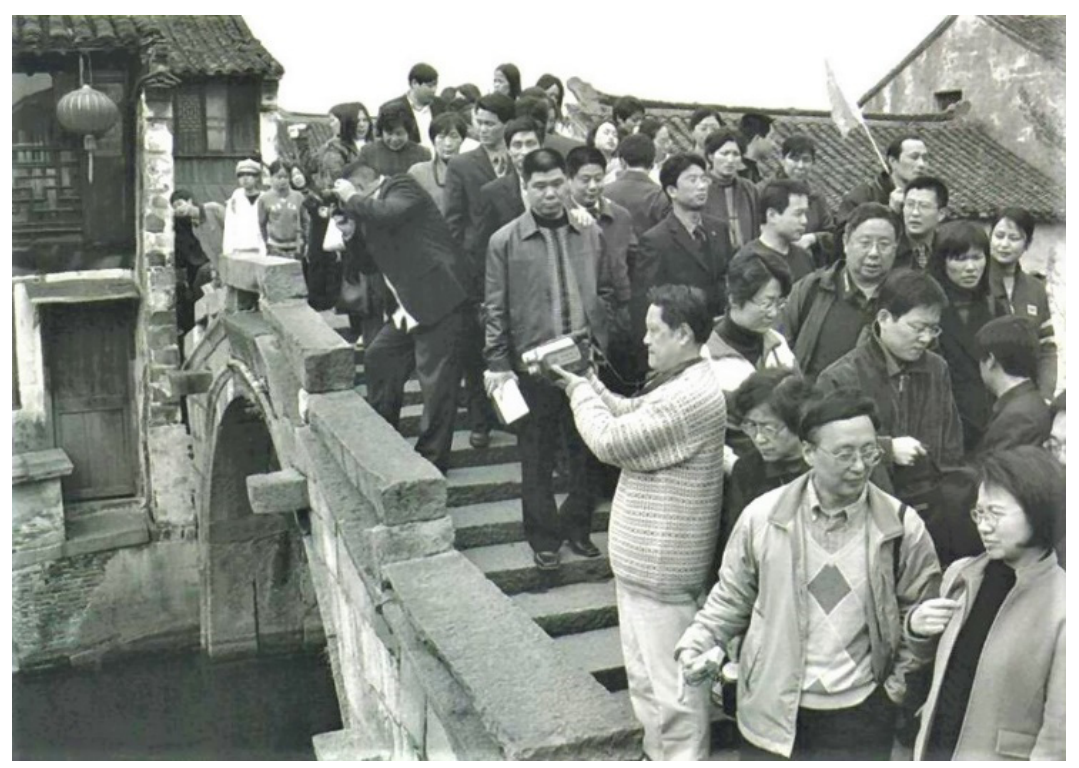

Figure 31. Mass tourist flow, Zhouzhuang, 2005 (photo from [30] p. 80).

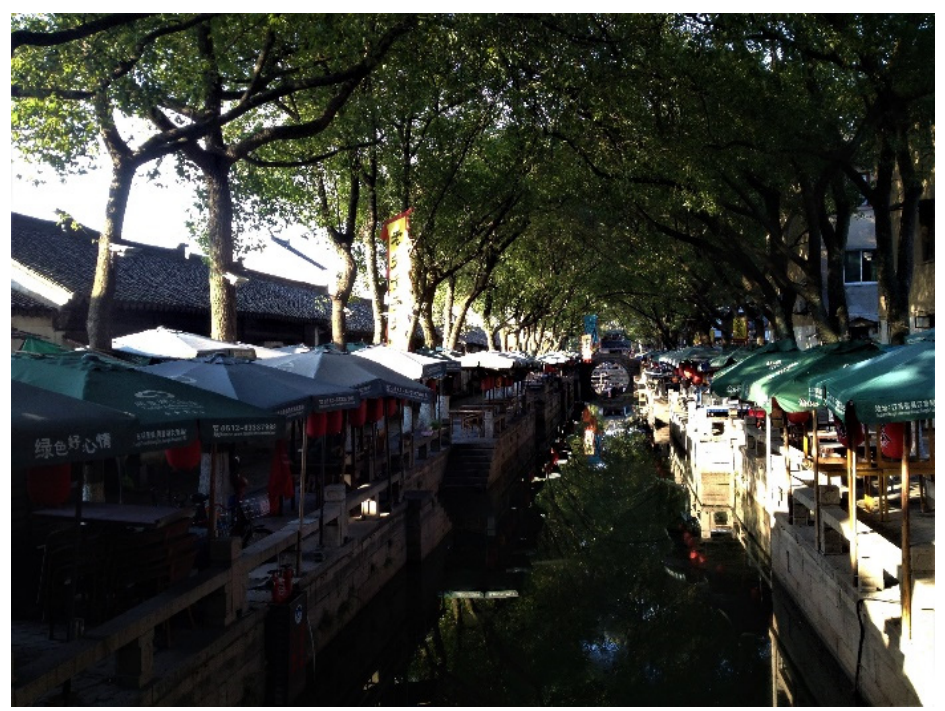

Figure 32. Canal banks of Tongli transformed into open air restaurants ready to receive the mass tourist flux (photo by the author, 2014). 


\section{In Conclusion: a Critical Assessment of Ruan Yisan's Interventions as a Basis for Future Research}

Leaving aside more recent developments, such as those fostered by the above-mentioned 11th Five-Year Plan, which considered tourism "as a growth sector boosting internal consumption and helping to fight poverty, especially in rural areas" [11] (p. 8), I would like to conclude with a critical assessment of Ruan Yisan's planning interventions in the water towns, set within their historical context.

Professor Ruan operated in the years immediately after 1979, when China's built heritage ceased to be a target for destruction in the name of political ideology, ${ }^{9}$ but continued to be endangered because of the country's accelerated urbanisation and modernisation. His intervention was an attempt to save historic towns from the grip of industrialisation, ${ }^{10}$ promoting an alternative path for their development: that of tourism. The legislative framework of the 1980s and 1990s, as we saw, gave him the planning tools and conceptual support needed to proceed with his preservation interventions; this was exemplified in the case of Nanxun, which, as we have seen, had already been included in 1986 in the official List of Precious Historic Cities (Lishi Wenhua Mingcheng), giving it legal protection. However, legal support in itself was not sufficient, unless accompanied by financial resources. The central government's understanding and guidelines, as previously discussed, were clear on this point: conservation should "sustain and preserve traditional characteristics with appropriate urban development" [29] (p. 411), which implied that conservation and development (and more specifically tourist development) had to be mutually sustaining. The government's decision to assign the protection of historic cities to the Ministry of Construction and Urban and Rural development (MOHURD), by contrast with the protection of "monuments and sites", which is assigned to the National Office of Cultural Affairs, clearly defined the national policy on conservation. Decisions regarding what represents tradition and built heritage, how they should be preserved, interpreted or reutilised, are thereby entrusted to local authorities, architects and planners. This has given the opportunity for farsighted and concerned planners, like Ruan Yisan, to promote and implement their conservation plans, but also gives scope for local governments more interested in the economic returns on their urban heritage interventions, to misinterpret them-as exemplified in the case of Wuzhen. Whitehand and Gu [23] (pp. 648-649) have already highlighted that the incorporation of urban conservation in urban planning developments in China favoured a top-down approach, which in recent years has often fostered land-use planning procedures as urban conservation methods. Hundreds of projects, from Xintiandi (Shanghai) [29] and Qianmen (Beijing), to Daming palace (Xian) [58] up to the rebuilding the old city of Datong [59], fall under this category, heavily criticised "for their inauthentic character, gentrification and displacement of old residents" [60] (pp. 170-171). Not only is heritage tourism characterised by a "top-down" government approach, but the formulation and implementation of urban conservation plans also show a similar tendency, "in which the independence of the heritage profession and the applicability of conservation planning principles" is doubtful [16] (p. 458) [61].

A counter-balance to this tendency might lie in furthering research on Chinese urban history and conservation from a methodological and theoretical viewpoint [16,31], including the promotion of a systematic morphological and typological analysis of urban patterns and of their historical developments [62-64]. As Whitehand and Gu put it, "conservation methods in China are largely based on descriptions of the characteristics of urban landscapes", and not on analysis. "Vague interpretations of the historical development of urban form have been major causes of inappropriate restoration and redevelopment plans and the ineffectiveness of the implementation of planning." [23] (p. 650). This also holds true for Ruan Yisan's conservation planning, based as it is on inadequate analysis of urban patterns and on the identification of protected areas on a street-river basis rather than a neighbourhood

9 I am referring to the years of the cultural revolution and the movement for "destroying the old four".

10 In the years between 1980 and 2010 Zhejiang province saw a population increase from $14 \%$ to $62 \%$, compared to the national average increase of $50 \%$ [55]. 
basis (Figure 33) [57], resulting in a restoration process that has focused mainly on the shop-houses lining the streets (mainly commercial) or the river banks (principally for tourist use), rather than whole neighbourhood blocks (largely left to be renovated by their low-income residents).

The dearth of research on Chinese urban history from a methodological and theoretical viewpoint has also favoured a dependency on Western methods and trends. The long-term cooperation with France, and specifically with the Observatoire de l'architecture de la Chine contemporaine, initiated by Ruan Yisan in 1998, illustrates this point. This tradition is still ongoing, with Professor Zhou Jian ${ }^{11}$-a younger member of Ruan Yisan's Tongji University team, now responsible for the plans of Tongli (2011) and Zhenze (2017) —who, in order to promote a more balanced development approach for Tongli, introduced the principle of "integrated protection", inspired by the "French experience of secteurs sauvegardés and the Zones de protection du patrimoine architectural, urbain et paysager (ZPPAUP) [ ... ] with the idea of maintaining Tongli as a living city", as Alain Marinos, responsible for French-Chinese cooperation in this field, informed us [35] (p. 19), [11].

Notwithstanding the increasing level of attention recently attracted by heritage conservation [32,33], Chinese urban conservation still lacks a systematic analytical approach to its traditional settlements: on this basis, this paper offers as its contribution to add further grounds to the existing evidence for developing research on Chinese urban history and conservation from a methodological and theoretical viewpoint.

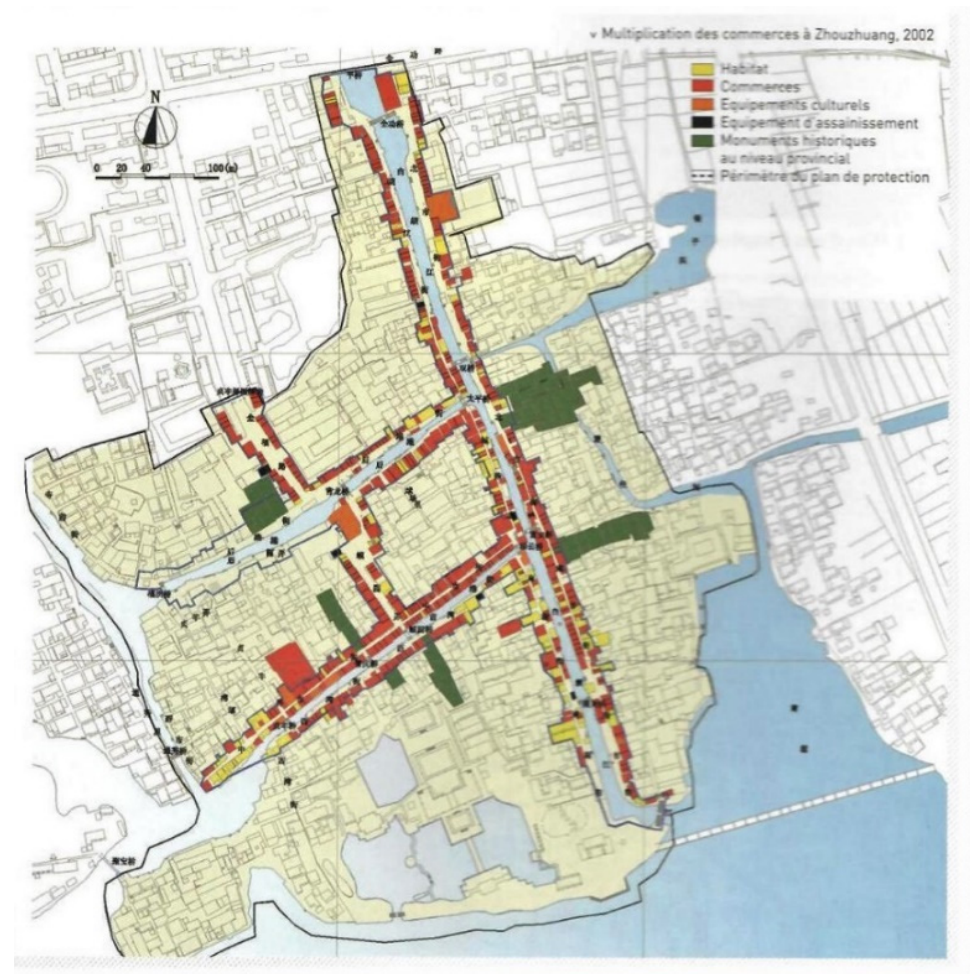

Figure 33. Plan of Zhouzhuang, 2002, showing in red the multiplication of commercial activities along the street-river axis, which was the basis and focus of the protection plan drafted by Professor Ruan Yisan in 1986 (photo from [30] p. 81).

Acknowledgments: This paper draws on the research work undertaken over the last six years in the context of a number of different research projects (Bilateral Agreement between National Research Council

11 Professor Zhou Jian is currently also the Director of the World Heritage Institute for Training and Research for the Asia and the Pacific Region, under the auspices of UNESCO - WHITRAP. Available online http://www.whitr-ap.org/index.php? classid=1459 (accessed on 30 November 2018). 
of Italy-CNR-ICVBC and the World Heritage Institute for Training and Research for the Asia and the Pacific Region under the auspices of UNESCO-WHITRAP since 2013; European financed IRSES-People project "Planning, Urban Management and Heritage-PUMAH" (2012-2016); Bilateral project between CNR and the Chinese Academy of Cultural Heritage - $\mathrm{CACH}$ on "Routes of culture: enhancement and management of large scale heritage sites. Via Appia-Roman Consular street-and the Grand Canal of China" from 2016 to 2018). I owe much of my understanding and knowledge of Chinese heritage planning to the colleagues I have been working with and to the help and support they offered me. An early version of this paper was presented on December 4-6, 2017 to the Conference organised by Andrew Law, Newcastle University on "Risks to life, heritage, and community on the Yangtze River". I am very grateful for the comments received then, among others, of Yiwen Wang, Giulio Verdini and Andrew Law. The author is greatly indebted to the reviewers' comments.

Conflicts of Interest: The author declares no conflict of interest.

\section{References}

1. Ball, P. The Water Kingdom. A Secret History of China; The Bodley Head: London, UK, 2016.

2. Xu Yang Gu Su Fan Hua Tu [Xu Yang's Flourishing City Gusu]; Commercial Press: Hong Kong, China, 1988.

3. UNESCO World Heritage List. The Grand Canal. Available online: http://whc.unesco.org/en/list/1443 (accessed on 20 November 2017).

4. Ruan, Y.S. Water Towns of the Yangtze River in China; a First Edition of This Book with 40 Pages Less Entitled Water Towns South of the Yangtze River, Was Published in 2004; Shanghai People's Fine Arts Publishing House: Shanghai, China, 2009.

5. Yu, B. Engineering Philosophy in the Grand Canal. In China and Italy: Routes of Culture, Valorisation and Management; Porfyriou, H., Yu, B., Eds.; CNR Ed: Rome, Italy, 2018; pp. 139-149. Available online: http://www.icvbc.cnr.it/Attivit\%C3\%A0/Editoria.html (accessed on 17 December 2018).

6. Fei, X.T. (Ed.) Small Towns in China. Functions, Problems \& Prospects; New World Press: Beijing, China, 1986.

7. Ruan, Y. Jiangnan Shuixiang Guzhen Baohushijian [Practices for the Conservation of the Water Cities of Jiangnan]; National Research Centre of Historic City, Tongji University: Shanghai, China, 2000.

8. Yu, F. Small bridges, flowing streams and cottages. An introduction to Shaoxing, an area of rivers and lakes. In Chinese Vernacular Dwelling; Shan, D., Ed.; China Intercontinental Press: Beijing, China, 2004; pp. 69-82.

9. Xu, Y. City in Space and Time: Development of the Urban Form and Space of Suzhou until 1911. Ph.D. Thesis, The University of Edinburgh, Edinburgh, UK, 1997. Available online: https://www.era.lib.ed.ac.uk/handle/ 1842/15758?show=full (accessed on 18 November 2018).

10. Even the Big City of Suzhou, Famous for Its Classical Gardens and UNESCO World Heritage Site, Is Presented with This Branding in Wikipedia, Which Cites the New York Times and The Times. Wikipedia: Suzhou. Available online: https://en.wikipedia.org/wiki/Suzhou (accessed on 18 November 2017).

11. Bellocq, M. Le patrimoine culturel comme ressource touristique: Le bourg ancien de Tongli, province du Jiangsu. L'Espace Géogr 2017, 46, 346-363, The English version of this article translated by Aruna Popuri, Cultural Heritage as Tourist Draw: The Ancient town of Tongli in the Jiangsu Province; pp. 1-18. Available online: https://www.cairn-int.info/article-E_EG_464_0346--cultural-heritage-as-touristdraw.htm (accessed on 17 December 2018).

12. Official Presentation of Wuzhen Local Administrators during the Visit with Prof. Lu Bin of Peking University on 20 March 2015 in the Context of the European Project: PUMAH (2012-2016). Available online: https://www.ncl.ac.uk/guru/research/projects/planningurbanmanagementandheritagepumah.html (accessed on 18 November 2017).

13. Suzhou Statistical Yearbook. 2016. Available online: http://www.sztjj.gov.cn/tjnj/2016/indexch.htm (accessed on 18 November 2017).

14. The Township of Tong Li in Suzhou China. Available online: http://www.suzhou.gov.cn (accessed on 18 November 2017). (In English)

15. Ruan, Y.S.; Li, Z.; Lin, L. Old Towns of Jiangnan: Conservation of Historical Architecture and Built Environment; Shanghai People's Fine Arts Publishing House: Shanghai, China, 2010.

16. Xie, J.; Heath, T. Conservation and revitalization of historic streets in China: Pingjiang Street, Suzhou. J. Urban Des. 2017, 22, 455-476. [CrossRef]

17. Johnston, S. The Ancient City of Suzhou: Town Planning in the Sung dynasty. Town Plan. Rev. 1983, 54, 194-222. [CrossRef] 
18. Wu, F. Real estate development and the transformation of urban space in China's transitional economy, with special reference to Shanghai. In The New Chinese City: Globalisation and Market Reform; Logan, J.P., Ed.; Blackwell Publishers Ltd.: Oxford, UK, 2002.

19. Zhu, J.M. Urban Development under Ambiguous Property Rights: A Case of China's Transition Economy. Int. J. Urban Reg. Res. 2002, 26, 41-57. [CrossRef]

20. Ren, X.F. Forward to the past: Historical preservation in globalizing Shanghai. City Community 2008, 7, $23-43$. [CrossRef]

21. Wu, F.L.; Xu, J.; Yeh, A.G. Urban Development in Post-Reform China: State, Market, and Space; Routledge: London, UK; New York, NY, USA, 2007.

22. Broudehoux, A.M. The Making and Selling of Post-Mao Beijing; Routledge: London, UK, 2004.

23. Whitehand, J.W.R.; Gu, K. Urban conservation in China. Historical development, current practice and morphological approach. Town Plan. Rev. 2007, 78, 643-670. [CrossRef]

24. Fresnais, J. La Protection du Patrimoine en République Populaire de Chine 1949-1999; Editions du C.T.H.S.: Paris, France, 2001.

25. Sun, S. (Ed.) Chengshi Guihua Fagui Duben [Readings in Urban Planning Laws and Regulations]; Tongji University Press: Shanghai, China, 1998; pp. 189-199.

26. Jia, Y. The Study on Main Issues of Chinese and Italian Historic Centers' Conservation Based on A Comparative Perspective. Ph.D. Thesis, Politecnico di Torino, Turin, Italy, 2014.

27. Wang, J. Conservation Policies and Planning of City Historic Sites. City Plan. Rev. 2004, 10, 68-73.

28. Zhang, S. An Introduction to Integrated Conservation: A Way for the Projection of Cultural Heritage and Historic Environment; Tongji University Press: Shanghai, China, 2008.

29. Chen, F. Traditional architectural forms in market oriented Chinese cities: Place for localities or symbol of culture? Habitat Int. 2011, 35, 410-418. [CrossRef]

30. Ged, F.; Marinos, A. (Eds.) Ville et Patrimoines en Chine; Catalogue Edité par l'Observatoire de L'architecture de la Chine Contemporaine D'après L'exposition Concue avec la Fondation Ruan Yisan à: Paris Oct 2009-Jan. 2010, Berlin Automne 2009, Londres Automne 2010; the Citation Is from the Preface to the Volume of Wang Jinghui (Consultant of MOHURD); Citè de L'architecture \& du Patrimoine: Paris, France, 2010.

31. Xie, J.; Heath, T. Heritage led Urban Regeneration in China; Routledge: London, UK; New York, NY, USA, 2017.

32. Yang, H.X.; Liu, X. (Eds.) Collection of International Symposium on Conservation of Historical Cities and Buildings; The University of Hunan Press: Changsha, China, 2006.

33. College of Architecture \& Urban Planning Tongji University (Ed.) Urban Heritage Conservation; China Architecture \& Building Press: Beijing, China, 2010.

34. Hecht, B. L'engagement du professeur Ruan Yisan. Monde Chinois 2010, 22, 27-28.

35. Marinos, A. Le partenariat franco-chinois en matière de protection du patrimoine. Monde Chinois 2010, 22, $17-21$.

36. $\mathrm{Su}, \mathrm{X}$. Reconstructing Tradition: Heritage Authentication and Tourism-Related Commodification of the Ancient City of Pingyao. Sustainability 2018, 10, 670. Available online: https://www.mdpi.com/2071-1050/10/ 3/670 (accessed on 20 December 2018). [CrossRef]

37. Wang, S.Y. From a Living City to a World Heritage City-Authorized Heritage Conservation and Development Policies and Their Impact on the Local Community. Int. Dev. Plan. Rev. 2012, 34, 1-17. [CrossRef]

38. Ancient City of Pin Yao-Unesco WHC. Available online: https://whc.unesco.org/en/list/812 (accessed on 30 November 2018).

39. Ruan Yisan Foundation. Available online: https://www.revolvy.com/page/Ruan-Yisan-Heritage-Foundation (accessed on 30 November 2018).

40. University of Notre Dame, Henry Hope Reed Award. Professor Ruan Yisan Has Been Awarded the Prize in 2014. Available online: https://architecture.nd.edu/news-events/events/henry-hope-reed-award/recipients/ professor-ruan-yisan/ (accessed on 30 November 2018).

41. Ruan, Y.S. Nanxun: Ancient Town in Jiangnan; Foreign Languages Press: Beijing, China, 1991.

42. Ruan, Y.S. Shui Xiang Ming Zhen Nanxun; Tong Ji Da Xue Chu Ban She: Shanghai, China, 1993.

43. Chen, H. Ancient Towns around Shanghai; Foreign Languages Press: Beijing, China, 2010.

44. Johnson, L.C. (Ed.) Cities of Jiangnan in Late Imperial China; State University of New York Press: New York, NY, USA, 1993.

45. Ruan, Y.S. Nanxun; Zhejiang She Ying Chu Ban She: Hangzhou, China, 2002. 
46. Taunay, B. Le Tourisme Intérieur Chinois; Presses Universitaires de Rennes: Rennes, France, 2011.

47. Fan, C.; Wall, G.; Mitchell, C. Heritage retail centers, creative destruction and the water town of Luzhi, Kunshan, China. In Tourism in China. Destination, Cultures and Communities; Ryan, C., Gu, H., Eds.; Routledge: Oxford, UK, 2009; pp. 99-123.

48. Sofield, T.H.B.; Li, F.M.S. Tourism development and cultural policies in China. Ann. Tour. Res. 1998, 25, 362-392. [CrossRef]

49. Nanxun Water Town Tours. Available online: https://www.shanghaihighlights.com/nanxun-tour/ (accessed on 30 November 2018).

50. Yan, P. Tongli; Suzhou Daxue Chubanshe: Suzhou, China, 1998.

51. Li, Y.B.; Zhang, J.; Chen, Y.J. Image of landscapes in ancient water towns. Case study on Zhouzhuang and Tongli of Jiangsu province. Chin. Geogr. Sci. 2006, 16, 371-377.

52. Bellocq, M. The Cultural Heritage Industry in the PRC: What Memories Are Being Passed On? A Case Study of Tongli, a Protected Township in Jiangsu Province. China Perspect. 2006, 67, 22-32.

53. Zunxin, B. A propos de la «fièvre de la fin des Qing». Peut-on comparer les ères de réformes des fins du XIXe et du XXe siècles? Perspect. Chin. 1995, 27, 12-17. [CrossRef]

54. Ruan, Y.S. Wu Zhen; Zhejiang She Ying Chu Ban She: Hangzhou, China, 2002.

55. Knapp, R.G. Chinese Houses: The Architectural Heritage of a Nation; Tuttle Publishing: Singapore, 2005; pp. 120-132.

56. Wuzhen Official Website. Available online: http://en.wuzhen.com.cn/web/introduction?id=2 (accessed on 30 November 2018).

57. Ged, F. Protection du patrimoine et développement du tourisme: Quels enjeux pour quels territoires? Monde Chinois 2010, 22, 7-16.

58. Yu, J.L.; Zan, L. Xi'an and Daming Palace. In Heritage Sites in Contemporary China. Cultural policies and Management Practices; Zan, L., Yu, B., Yu, J., Yan, H., Eds.; Routledge: London, UK; New York, NY, USA, 2018; pp. 110-145.

59. Datong 2011. Available online: http://www.chinaheritagequarterly.org/articles.php?searchterm=027_datong. inc\&issue $=027$ (accessed on 30 November 2018).

60. Berg, P.O.; Björner, E. (Eds.) Branding Chinese Mega-Cities: Policies, Practices and Positioning; Edward Elgar Pub: Stockholm, Sweden, 2014.

61. Qian, F. China's Burra Charter: The formation and Implementation of the China Principles. Int. J. Herit. Stud. 2007, 13, 255-264. [CrossRef]

62. Whitehand, J.W.R.; Gu, K.; Whitehand, S.M. Urban morphology and conservation in China. Cities 2011, 28, 171-185. [CrossRef]

63. Abrahamson, D.B. Places for the gods: Urban planning as orthopraxy and heteropraxy in China. Environ. Plan. D Soc. Space 2011, 29, 67-88. [CrossRef]

64. Zhang, L. La Naissance du Concept de Patrimoine en Chine, XIX-XXe Siècles; Éditions Recherches IPRAUS: Paris, France, 2003.

(C) 2019 by the author. Licensee MDPI, Basel, Switzerland. This article is an open access article distributed under the terms and conditions of the Creative Commons Attribution (CC BY) license (http://creativecommons.org/licenses/by/4.0/). 